\title{
Sladek
}

\section{EFFECTS OF URBANIZATION ON \\ FLOODS IN THE DALLAS, TEXAS \\ METROPOLITAN AREA \\ REPORTS SECTION \\ COPY}

U. S. GEOLOGICAL SURVEY

Water-Resources Investigations 60-73
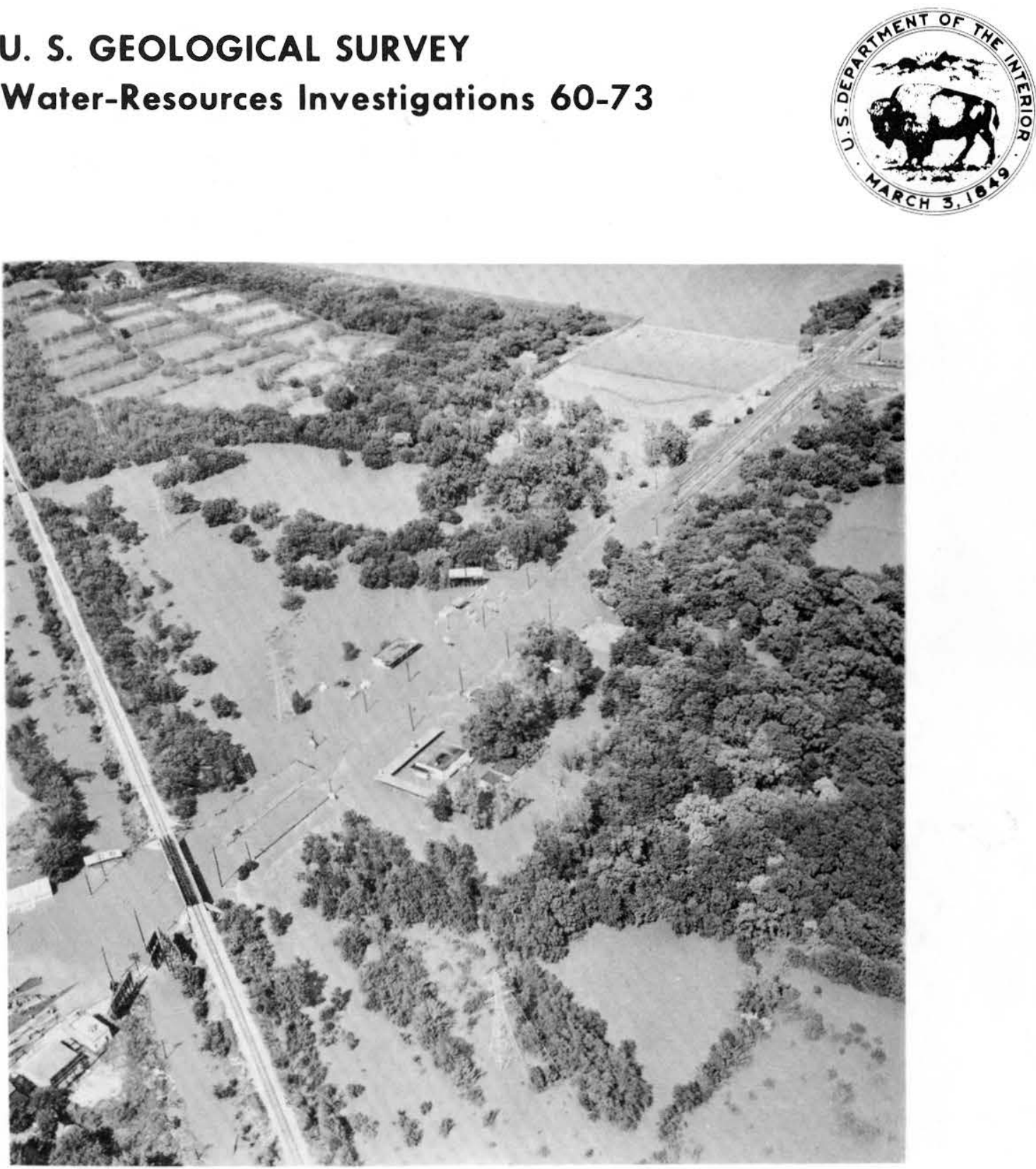

Prepared in cooperation with the city of Dallas 


\begin{tabular}{|c|c|c|c|}
\hline $\begin{array}{l}\text { BIBLIOGRAPHIC DATA } \\
\text { SHEET }\end{array}$ & 1. Report No. & & 3. Recipient's Accession No. \\
\hline \multirow{2}{*}{\multicolumn{3}{|c|}{$\begin{array}{l}\text { EFFECTS OF URBANIZAT } \\
\text { DALLAS, TEXAS, METRO }\end{array}$}} & $\begin{array}{l}\text { 5. Keport Date } \\
\text { January } 1974 \\
\end{array}$ \\
\hline & & & 6. \\
\hline \multicolumn{3}{|c|}{ George R. Dempster, J } & $\begin{array}{l}\text { 8. Performing Otganization Rept. } \\
\text { No. WRI } 60-73\end{array}$ \\
\hline \multirow{2}{*}{\multicolumn{3}{|c|}{$\begin{array}{l}\text { 9. Performing Otganization tiame and Address } \\
\qquad \begin{array}{l}\text { U.S. Geological Survey } \\
\text { Federal Building, 300 E. 8th Street } \\
\text { Austin, TX } 78701\end{array}\end{array}$}} & 10. Project/Task/Wrotk Unit No. \\
\hline & & & 11. Contract/Girant No. \\
\hline \multirow{2}{*}{\multicolumn{3}{|c|}{$\begin{array}{l}\text { 12. Sponsuring Organization Natne and Address } \\
\qquad \begin{array}{l}\text { U.S. Geological Survey } \\
\text { Federal Building, 300 E. 8th Strect } \\
\text { Austin, TX 78701 }\end{array}\end{array}$}} & $\begin{array}{l}\text { 13. Type of Report \& P'eriod } \\
\text { Covered } \\
\text { Final }\end{array}$ \\
\hline & & & 14. \\
\hline \multicolumn{4}{|c|}{$\begin{array}{l}\text { 15. Supplementaty Notes } \\
\text { Prepared in cooperation with the city of Dallas. }\end{array}$} \\
\hline \multicolumn{4}{|c|}{$\begin{array}{l}\text { 16. Abstracts The effects of urbanization on flood characteristics of streams in the } \\
\text { Dallas metropolitan area were studied by use of a digital model of the hydrologic } \\
\text { system, which was calibrated by using observed data from } 19 \text { storms in six basins to } \\
\text { estimate peak discharges and flood volumes and to simulate a } 57 \text {-year record of annual } \\
\text { peak discharges in } 14 \text { basins. The flood-frequency characteristics were defined by } \\
\text { fitting the simulated } 57-y e a r \text { record to a log-Pearson Type III distribution. } \\
\text { Regional peak-discharge equations, which can be used to determine the maximum } \\
\text { rates of discharge that could be expected to be equalled or exceeded on the average of } \\
\text { once in } 1.25,2 \text {, } 5 \text {, } 10 \text {, } 25 \text {, and } 100 \text { years, were derived from multiple-regression } \\
\text { analyses. The relationships among flood frequency, drainage arca, and a coefficicnt } \\
\text { of impervious area are given in a nomograph, } \\
\text { The data indicate that in a fully developed residential area, with } 37 \text { percent } \\
\text { impervious area, the average annual dircct funoff is about double that of an } \\
\text { undeveloped area. }\end{array}$} \\
\hline \multicolumn{4}{|c|}{ 77. Key Words and Decument Analysis. 17o. Descriptors } \\
\hline \multicolumn{4}{|c|}{ 17b. Identifiers/Open-Finded Terms } \\
\hline \multicolumn{4}{|c|}{ Urban hydrology, multiple-regression analyses. } \\
\hline \multicolumn{4}{|c|}{ 17c. cosati Field/Group $\$ 2 \mathrm{E}, \phi 4 \mathrm{C}$} \\
\hline \multirow{2}{*}{\multicolumn{2}{|c|}{$\begin{array}{l}\text { 18. Availability Statement } \\
\text { No restriction on distribution. }\end{array}$}} & $\begin{array}{l}\text { 19. Security Class (This } \\
\text { Report) } \\
\text { LNCLASSIEIFD }\end{array}$ & $\begin{array}{l}\begin{array}{l}21 . \text { No. of Pages } \\
55\end{array} \\
\end{array}$ \\
\hline & & $\begin{array}{l}\text { 20. Security Class (This } \\
\text { Page } \\
\text { LICI.ASSIFIE.D }\end{array}$ & 22. Price \\
\hline
\end{tabular}




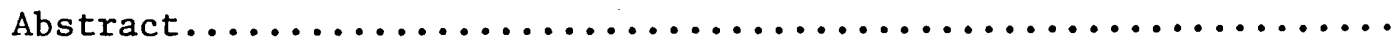

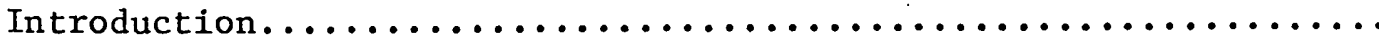

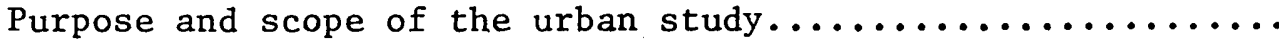

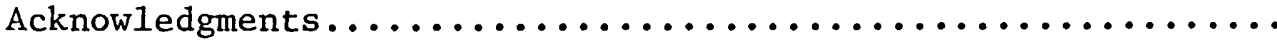

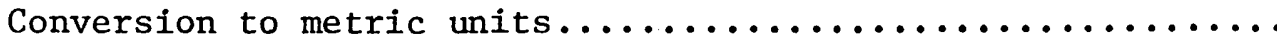

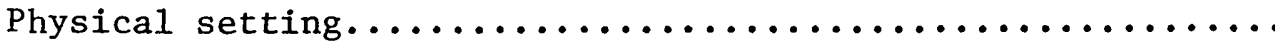

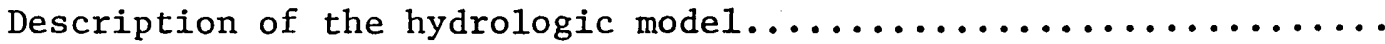

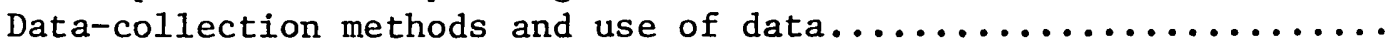

Drainage area and main-channel length and slope............

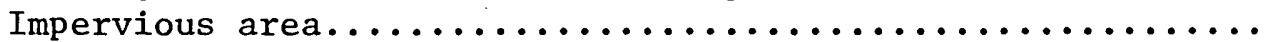

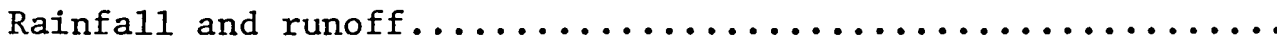

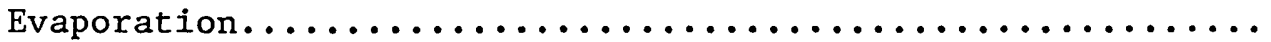

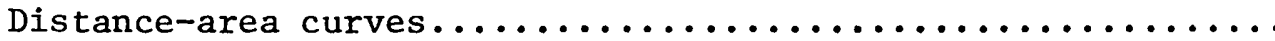

Comparison of observed and computed peak discharges.............

Extension of flood records in time at gaging stations............

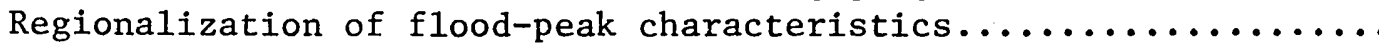

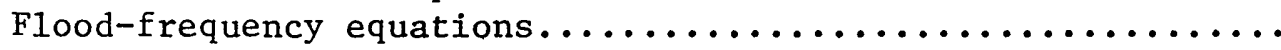

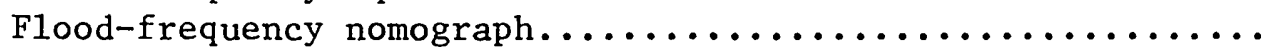

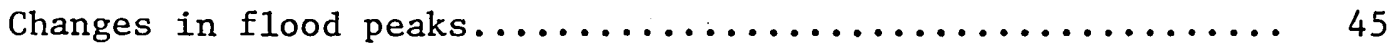

Changes in the volume of annual runoff............... 47

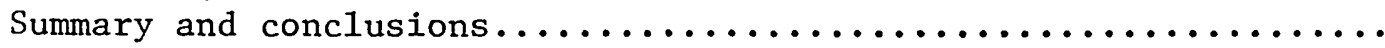

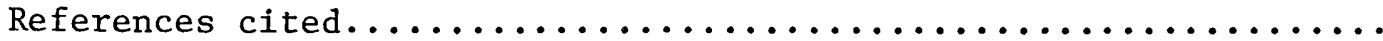


Figure 1. Map of Texas showing the location of the Dallas metropolitan area....................... 4

2. Schematic diagram of the hydrologic model.......... 6

3. Map showing locations of drainage basins, stream-

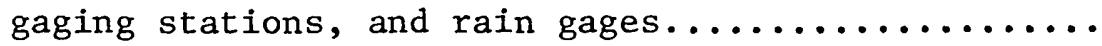

4. Scatter diagram of observed and computed peak

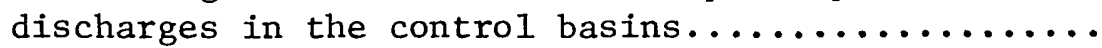

5. Scatter diagram of observed and computed peak

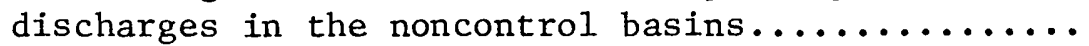

6. Flood-frequency curves for six gaging stations based on simulated peak discharges for $1914-70 . .$. .

7. Flood-frequency curves for eight gaging stations based on simulated peak discharges for $1914-70 \ldots .$. .

8. Nomograph showing the relation between flood frequency, drainage area, and a coefficient of

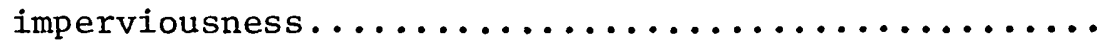

omparison showing the effects of urbanization on the 50-year peak discharges in Dallas and

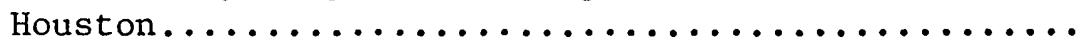

10. Graph showing the relation of effective impervious area to the ratio of urban runoff to rural runoff... 4

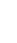
. 
EFFECTS OF URBANIZATION ON FLOODS IN THE

DALLAS, TEXAS, METROPOLITAN AREA

\section{By}

George R. Dempster, Jr.

U.S. Geologica1 Survey

\section{ABSTRACT}

The effects of urbanization on flood characteristics of streams in the Dallas metropolitan area were studied by use of a digital model of the hydrologic system. The model was calibrated by using observed rainfall and runoff data from 19 storms in six basins having various degrees of urbanization. The calibrated models were used with a 57year rainfall record to simulate 57-year records of annual peak discharges in 14 basins. The flood-frequency characteristics were defined by fitting the simulated 57-year records to 10 -Pearson Type III distributions.

Regional peak-discharge equations, which can be used to determine the maximum rates of discharge that could be expected to be equaled or exceeded on the average of once in $1.25,2,5,10,25$, and 100 years, were derived from multiple-regression analyses. The relationships among flood frequency, drainage area, and a coefficient of impervious area are given in a nomograph.

The analyses indicate that in a fully-developed residential area, the flood peaks will be 1.2 to 1.4 times those from an undeveloped area; and the annual direct runoff will be about double that from an undeveloped area. Data were not sufficient to determine the increase in runoff from a highly industrialized area where the effective imperviousness approaches 100 percent. 


\section{Purpose and Scope of the Urban Study}

A program to define the effects of urban development on flood characteristics of streams in the Dallas metropolitan area was begun in 1962 by the U.S. Geological Survey in cooperation with the city of Dallas. The purpose of this study was to determine the effects of urbanization on the magnitude and frequency of floods, to establish a regional floodfrequency relationship of sufficient accuracy to be used for the design of drainage systems, and to determine the relative importance of the physical characteristics that influence the hydrology of an urban area.

The analytical methods used encompass general statistical concepts. A digital model of the hydrologic system, which was calibrated by using data from 19 storms in each of six basins, was used to simulate 57-year records of annual peak discharges for 14 drainage basins.

The simulated 57-year records were used to define flood-frequency relations by fitting to the log-Pearson Type III distribution (U.S. Water Resources Council, 1967, p. 7-9). Regional peak-discharge equations, which can be used to determine the maximum rates of discharge that could be expected to be equaled or, exceeded at average intervals of $1.25,2,5,10,25,50$, and 100 years, were derived from multipleregression analyses.

The general relationships of flood-peak characteristics, drainage area, and degree of urbanization can be used to estimate the effects of varying degrees of urbanization and to estimate flood-peak characteristics at ungaged sites.

\section{Acknowledgments}

The author acknowledges the assistance of Mr. Harry H. Stirman, Director of the Department of Public Works of the city of Dallas, and Mr. Donald H. Deere, Drainage Engineer, Dallas Department of Public Works. Mr. Robert W. Lichty, Research Hydrologist, U.S. Geological Survey, assisted with the development of computer applications and modeling techniques. 
For those readers interested in using the metric system, metric equivalents of English units of measurements are given in parentheses. The English units used in this report may be converted to metric units by the following conversion factors:

\section{From}

Square miles $\left(\mathrm{mi}^{2}\right)$

Miles (mi)

Feet (ft)

Square feet $\left(f t^{2}\right)$

Inches (in)

Cubic feet per second $\left(\mathrm{ft}^{3} / \mathrm{s}\right)$
Multiply by

2.590

1.609

.3048

.0929

2.54

.02832
To obtain

Square kilometers

Kilometers

Meters

Square meters

Centimeters

Cubic meters per second

\section{Physical Setting}

The Dallas metropolitan area is in north Texas about 250 miles (400 kilometers) from the Gulf of Mexico (fig. 1). The city has grown rapidly in recent years, and presently (1973) very little land remains undeveloped.

The altitude ranges from about 500 to about 700 feet (150 to 210 meters) above mean sea level. In the upland areas, outcrops of limestone, chalk, and marl are surrounded by a thin mantle of soil. The soil mantle becomes much thicker and more extensive in the lowland areas. The soils are mostly clays that are dark colored and extremely sticky when wet. As with most clays, they show marked changes in volume with changes in the moisture content. During dry periods, numerous cracks develop in the clay and it becomes highly permeable; but almost immediately after wetting, the clay expands and the cracks rapidly close, thereby reducing the permeability. In residential areas and public parks, extensive watering throughout most of the year generally reduces the cracking. 


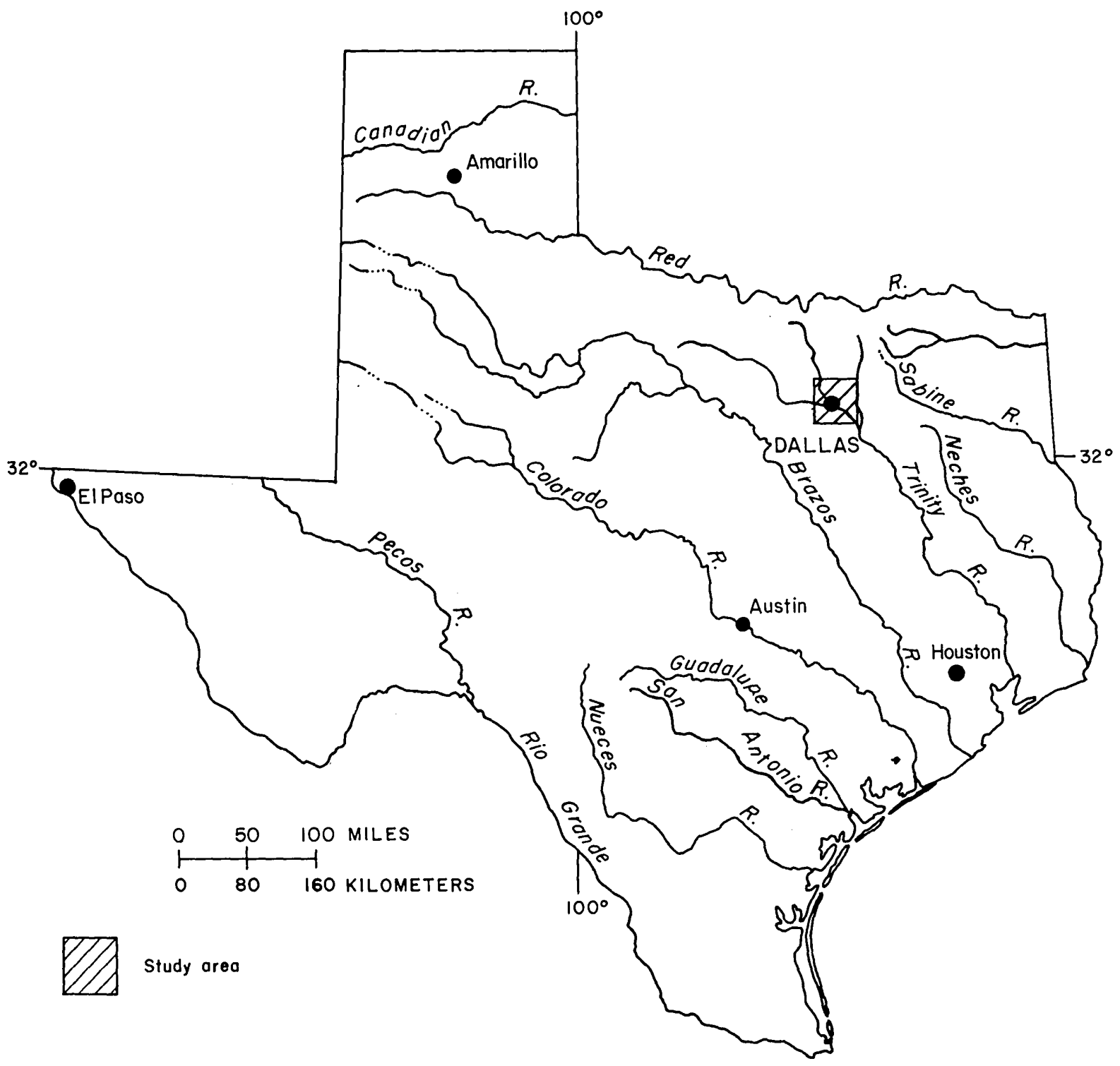

FIGURE 1.-Map of Texas showing the location of the Dallas metropolitan area 
The climate of Dallas is generally temperate with hot summers and mild winters. Mean temperatures range from $45^{\circ} \mathrm{F}\left(7.2^{\circ} \mathrm{C}\right)$ in January to $85^{\circ} \mathrm{F}\left(30^{\circ} \mathrm{C}\right)$ in July. The most common storms are thunderstorms that occur frequent1y in the spring and sumer. Long-duration low-intensity storms triggered by southward-moving continental polar fronts occur during the fall and winter. In late summer and early fall, hurricanes moving inland from the Gulf of Mexico cause some of the heaviest rainfall. Individual storms, although most frequent in the spring, may cause serious flooding during any season. Mean annual rainfall at Dallas for 1913-70 was 34.90 inches ( 88.6 centimeters). Lake evaporation usually exceeds rainfall from late March to early November.

The major stream draining the area is the Trinity River, which divides the city into two parts. The principal tributaries are Joes Creek, Bachman Branch, Turtle Creek, White Rock Creek, Coombs Creek, Cedar Creek, and Fivemile Creek. Most streams and their tributaries have well incised channels with steep banks of limestone, particularly in the upper reaches. The average channel slopes commonly exceed 30 feet per mile ( 5.7 meters per kilometer).

\section{DESCRIPTION OF THE HYDROLOGIC MODEL}

A digital model developed by Dawdy, Lichty, and Bergmann (1972) and modified by Lichty (written commun., 1971) was used to simulate long records of peak discharges under existing conditions of urbanization. The structure of the model is shown by the diagram on figure 2. The input parameters are identified in table 1 . Figure 2 shows the general sequence of computations and shows that the output from one component is the input to the next.

The antecedent-moisture accounting component (fig. 2), which is a more sophisticated version of the antecedent-precipitation index (API), measures the effects of antecedent conditions on the infiltration component. The infiltration component is based on an equation described by Philip (1954), in which infiltration rates are computed as a function of soil moisture and rainfall intensity. Infiltration does not occur in impervious areas, but some retention does occur. The model assumes 0.05 inch ( 0.12 centimeter) of water depth as the maximum retention in an impervious area.

The surface-routing component (fig. 2) is based on unit hydrograph concepts (Sherman, 1932), and assumes a conceptual model composed of linear reservoirs and channels. Rainfall excess is converted into flood hydrographs by procedures representing the effects of varying travel times and reservoir delays, which are derived from distance-area curves. The derivation assumes that travel time and reservoir delay are proportional, but some flexibility is permissible. 


\begin{tabular}{|l|l|l|}
\hline $\begin{array}{l}\text { ANTECEDENT-MOISTURE } \\
\text { ACCOUNTING COMPONENT }\end{array}$ & $\begin{array}{c}\text { INFILTRATION } \\
\text { COMPONENT }\end{array}$ & $\begin{array}{c}\text { ROUTING } \\
\text { COMPONENT }\end{array}$ \\
\hline
\end{tabular}

INPUT DATA

\begin{tabular}{|c|c|c|}
\hline $\begin{array}{l}\text { Daily rainfall } \\
\text { Daily pan evaporation } \\
\text { Initial estimates }\end{array}$ & $\begin{array}{l}\text { Unit rainfall } \\
\text { BMS (from moisture } \\
\text { SMS } \begin{array}{c}\text { accounting } \\
\text { component) }\end{array}\end{array}$ & $\begin{array}{l}\text { Rainfall excesses } \\
\text { (from pervious area infil- } \\
\text { tration and impervious } \\
\text { area retention component) }\end{array}$ \\
\hline
\end{tabular}

COMPUTATIONAL OPERATION AND PARAMETERS

\begin{tabular}{|c|c|c|}
\hline $\begin{array}{l}\text { Saturated-unsaturated } \\
\text { soil moisture levels for } \\
\text { pervious area }\end{array}$ & $\begin{array}{l}\text { Average pervious area } \\
\text { infiltration and impervious } \\
\text { area retention }\end{array}$ & $\begin{array}{l}\text { Instantaneous hydrographs } \\
\text { from pervious and imperi- } \\
\text { ous areas }\end{array}$ \\
\hline $\begin{array}{c}\text { Parameter } \\
\text { EVC } \\
\text { RR } \\
\text { BMSM } \\
\text { DRN }\end{array}$ & $\begin{array}{c}\text { Variable } \\
\text { BMS } \\
\text { SMS } \\
\text { PARAMETER } \\
\text { SWF } \\
\text { KSAT } \\
\text { RGF }\end{array}$ & 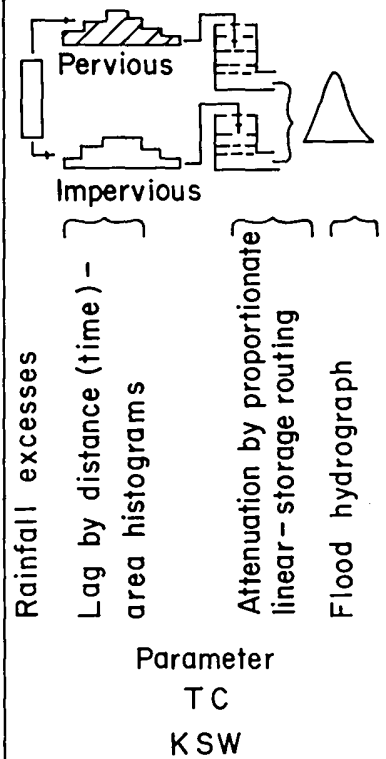 \\
\hline
\end{tabular}

OUTPUT DATA

\begin{tabular}{|c|c|c|}
\hline $\begin{array}{l}\text { Variable } \\
\text { BMS - Base-moisture storage } \\
\text { available } \\
\text { SMS - Surface-moisture con- } \\
\text { tent from infiltration }\end{array}$ & Rainfall excess & Discharge \\
\hline
\end{tabular}


Taible l.--Tdentification and definition of the parameters used in the digital model

\begin{tabular}{|c|c|c|c|}
\hline & Parameter & Units & \\
\hline Component & identifier & Units & Definition \\
\hline
\end{tabular}

EVC -- Pan coefficient that converts pan evaporation

to potential evapotranspiration.

Antecedent- $\quad$ RR -- Coefficient that proportions daily rainfall into

moisture

infiltration and surface runoff.

accounting

BMSM Inches Maximum effective soil-moisture storage volume at field capacity

DRN Inches Constant coefficient that controls drainage per hour rate of infiltrated soil moisture.

SWF Inches Capillary potential, or soil suction, at wetted front for field-capacity conditions.

Infiltration

RGF

$--$

Ratio that varies SWF over the soil-moisture range from wilting point to field capacity.

KSAT Inches Minimum saturated value of hydraulic conducper hour tivity used to determine infiltration rates.

TC

Minutes

Time characteristic for translation of rain-

Routing

fall excess by distance-area histrograms.

KSW Hours Time characteristic for linear reservoir routing. 
The model allows for the input of multiple rain-gage data for soil-moisture accounting. With multiple input, pairs of distance-area curves for pervious and impervious areas are required for each subbasin. The combination of distributed moisture accounting (multiple-input) and distributed routing make it possible to simulate the effects of both rainfall variability and urban development.

The measured impervious area was reduced and the pervious area was correspondingly increased to account for the flow from impervious surfaces into pervious areas as described subsequently. This reduced imperviousness is called effective imperviousness.

Model-parameter values are determined by a "hill climbing" optimization technique (Dawdy, Lichty, Bergmann, 1972), which uses bounded parameters (to constrain the parameters within reasonable limits) and an objective function. The objective function is the sum of the squared deviations of the logarithms of observed and simulated peak flows and (or) volumes. The combined objective functions give weight to both the storm peaks and storm volumes, while the single function weights either .storm peaks or storm volumes as specified.

The parameters are automatically adjusted to minimize the differences between observed and simulated data, as specified in the objective function. A set of parameters can be greater than, less than, or nearly an average of the "true" values. Because of interactions and assumptions, some error always exists. If the differences between observed and simulated data are assumed to be random, then the standard error of estimate, according to statistical analysis, is a meaningful measure of the error (Riggs, 1968).

The input data required for model calibration are rainfal1, pan evaporation, storm rainfall, discharge, initial-parameter estimates, base-flow estimates, and an appropriate number of distance-area curves.

\section{DATA-COLLECTION METHODS AND USE OF DATA}

Data for this study were collected during 1962-70 (water years) in seven principal basins and six subbasins (fig. 3 ), which ranged from rural to fully urbanized.

Urbanization within a basin may occur in the lower or upper parts, and construction and drainage improvement may occur concurrently or at differing times and rates. The states of urbanization that existed in 1968 are assumed as mean conditions for the period of record of rainfall and runoff. 


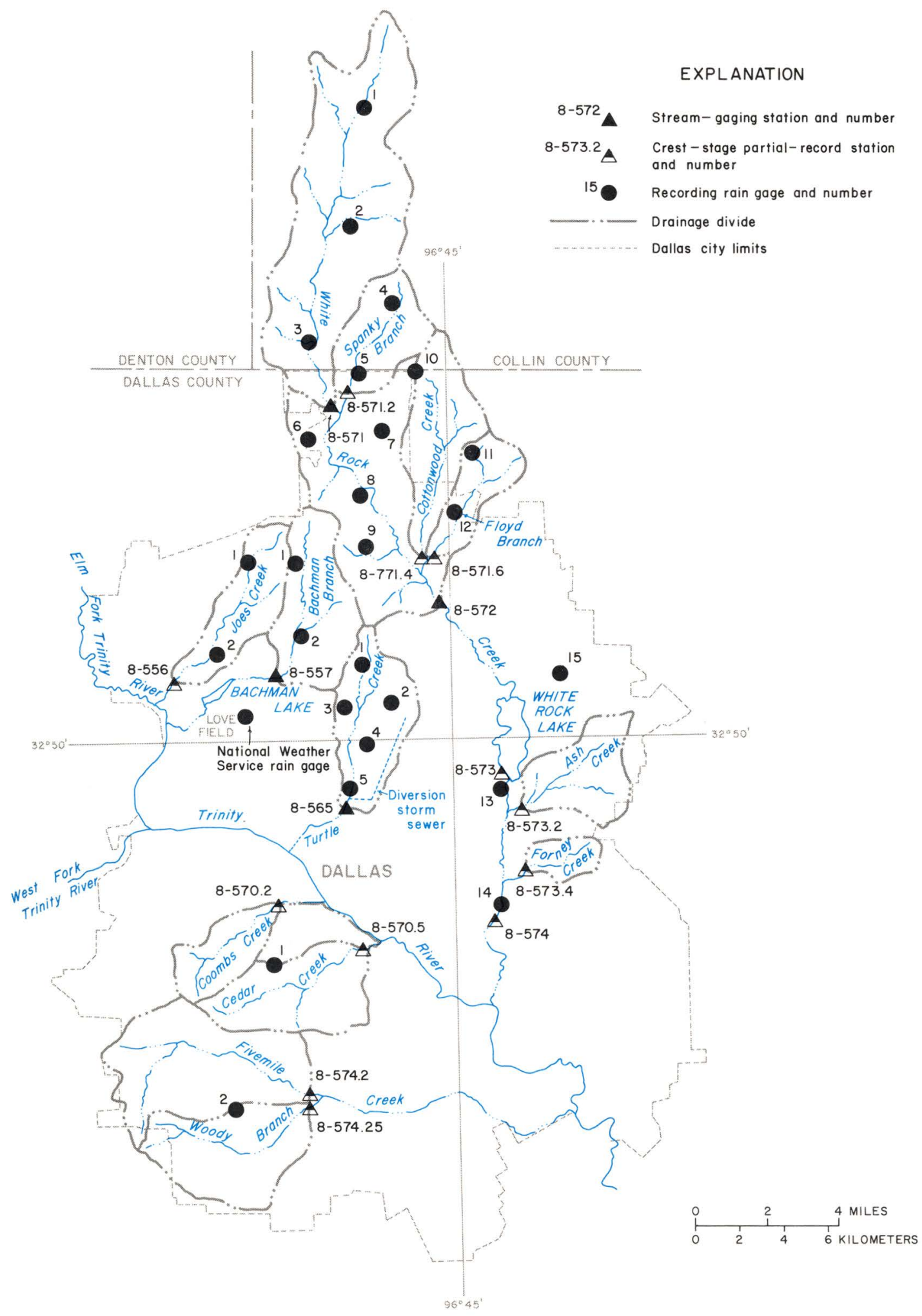

FIGURE 3. -Locations of drainage basins, stream-gaging stations, and rain gages 


\section{Drainage Area and Main-Channel Length and Slope}

Drainage areas were determined from U.S. Geological Survey topographic maps. Transfer of water from one drainage area to another by storm sewering is insignificant, except in the Turtle Creek Basin where the drainage from Mill Creek was diverted into Turtle Creek before the gaging station was established. Drainage areas are given in table 2 .

The main-channel length was calculated as the distance, in miles, along the longest watercourse from the gaging station to the basin divide. The average slope in feet per mile was obtained by dividing the difference in altitude between points located 10 and 85 percent of the distance upstream from the gaging station by the distance in miles between these points (Benson, 1964).

Length-slope ratios are defined as the quotient of the length and square root of the slope; this ratio is usually correlative with lag time. All length and slope data are given in table 2.

\section{Impervious Area}

The impervious area of each basin was obtained by: (1) Delineating the different city zoning categories (table 3 ) and the percentage of development on U.S. Geological Survey maps; (2) assuming that each zoning category had a constant average of impervious area; (3) planimetering the areas of each category and multiplying the areas by the constant average of impervious area for each particular category; and (4) summing the impervious areas of all categories to obtain the total impervious area. The percentage of residential, nonresidential, and total impervious area in each basin (based on mean 1968 conditions) is given in table 2 . Table 2 also gives the coefficients of imperviousness and topographic characteristics for each basin.

The coefficient of imperviousness, K, was developed by Carter (1961) to adjust peak discharges due to urban development. The value of $\mathrm{K}$ was determined by the formula:

$$
\mathrm{K}=1.00+.015 \mathrm{I}
$$

where

$I=$ the percentage of impervious area. 
Table 2.--Drainage area, percentage of impervious area, and topographic characteristics of

drainage basins in the Dallas metropolitan area

\begin{tabular}{|c|c|c|c|c|c|c|c|c|c|c|}
\hline \multirow[b]{2}{*}{$\begin{array}{r}\text { Gaging } \\
\text { station } \\
\text { (fig. } 2 \text { ) } \\
\end{array}$} & \multirow[b]{2}{*}{ Basin } & \multirow[b]{2}{*}{$\begin{array}{l}\text { Drainage } \\
\text { area } \\
\text { (sq } \mathrm{mi} \text { ) }\end{array}$} & \multicolumn{4}{|c|}{$\begin{array}{l}\text { Impervious area } \\
\text { (percentage) }\end{array}$} & \multirow{2}{*}{$\begin{array}{l}\text { Coefficient } \\
\text { of } \\
\text { impervious- } \\
\text { neşs } \\
\text { K } 3\end{array}$} & \multicolumn{3}{|c|}{$\begin{array}{c}\text { Topographic } \\
\text { characteristics }\end{array}$} \\
\hline & & & $\begin{array}{l}\text { Residen- } \\
\text { tial 1 }\end{array}$ & $\begin{array}{l}\text { Non- } \\
\text { residen- } \\
\text { tial }\end{array}$ & Total & $\begin{array}{l}\text { Effec } \ddot{~} \\
\text { tive } \underline{-}\end{array}$ & & $\begin{array}{l}\text { Length } \\
\text { (miles) }\end{array}$ & $\begin{array}{l}\text { Slope } \\
(\mathrm{ft} / \mathrm{mi})\end{array}$ & $\frac{\text { Length }}{\sqrt{\text { slope }}}$ \\
\hline (1) & (2) & (3) & (4) & (5) & (6) & (7) & (8) & (9) & (10) & (11) \\
\hline $8-556$ & Joes Creek & 7.51 & 25 & 10 & 35 & 26 & 1.52 & 6.42 & 31.0 & 1.15 \\
\hline $8-557$ & Bachman Branch & 10.0 & 24 & 6 & 30 & 22 & 1.45 & 6.32 & 31.6 & 1.12 \\
\hline $8-565$ & Turtle Creek & 7.98 & 30 & 17 & 47 & 37 & 1.70 & 5.90 & $4 / 28.1$ & 1.11 \\
\hline $8-570.2$ & Coombs Creek & 4.75 & 33 & 10 & 43 & 31 & 1.63 & 4.58 & 45.2 & .68 \\
\hline $8-570.5$ & Cedar Creek & 9.42 & 34 & 11 & 45 & 33 & 1.68 & 6.09 & 38.9 & .98 \\
\hline $8-571$ & $\begin{array}{l}\text { White Rock Creek above } \\
\text { Keller Springs Road }\end{array}$ & 29.4 & 0 & $5 / 1$ & 1 & $5 / 1$ & 1.00 & 13.5 & 15.2 & 3.46 \\
\hline $8-571.2$ & Spanky Branch & 6.77 & 0 & $5 / 1$ & 1 & $5 / 1$ & 1.00 & 4.88 & 36.6 & .81 \\
\hline $8-571.4$ & Cottonwood Creek & 8.50 & 19 & 11 & 30 & 23 & 1.45 & 7.04 & 32.1 & 1.24 \\
\hline $8-571.6$ & Floyd Branch & 4.17 & 13 & 13 & 26 & 21 & 1.39 & 4.84 & 38.6 & .78 \\
\hline $8-572$ & $\begin{array}{l}\text { White Rock Creek above } \\
\text { Greenville Avenue }\end{array}$ & 66.4 & 6 & 4 & 10 & 8 & 1.15 & 21.9 & 12.0 & 6.33 \\
\hline-- & $\begin{array}{l}\text { White Rock Creek between } \\
\text { Keller Springs Road and } \\
\text { Greenville Avenue } 6 /\end{array}$ & 37.0 & 11 & 3 & 14 & 10 & - & - & - & - \\
\hline $8-573.2$ & Ash Creek & 6.92 & 31 & 7 & 38 & 27 & 1.57 & 4.44 & 38.0 & .72 \\
\hline $8-573.4$ & Forney Creek & 1.84 & 12 & 3 & 15 & 11 & 1.22 & 2.72 & 56.4 & .36 \\
\hline $8-574.2$ & Fivemile Creek & 13.2 & 11 & 10 & 21 & 17 & 1.32 & 8.22 & 32.1 & 1.45 \\
\hline $8-574.25$ & Woody Branch & 11.5 & 9 & 4 & 13 & 10 & 1.20 & 6.12 & 40.1 & .97 \\
\hline
\end{tabular}

1/ Includes all residential zoning categories given in table 3 . All other categories are nonresidential.

2f Calculated as col. $4 \times 0.65+\operatorname{col} .5$.

3/ Equation for $\mathrm{K}=1.00+0.015 \mathrm{I}$, where $\mathrm{I}$ is total basin imperviousness from col. 6 .

4/ Based on April 28, 1966, flood profile (Mills and Schroeder, 1969); many channel dams across stream.

5/ Increased to 1.0 percent to account for paved roads and scattered buildings; these are rural basins.

6/ Intervening subbasin; runoff from area used in report. 
Table 3.--Zoning categories and average percentage of impervious area

\section{Zoning category \\ designation}

Description
Plot size

(sq ft)
Average impervious area (percentage)

$\begin{array}{llcr}\text { R-E } & \text { Residential estate } & >43,560 & 9 \\ \text { R-1 } & \text { Residential dwelling } & 43,560 & 17 \\ \text { R-1/2 } & \text { Residential dwelling } & 21,780 & 38 \\ \text { R-16 } & \text { Residential dwelling } & 16,000 & 43 \\ \text { R-10 } & \text { Residential dwelling } & 10,000 & 46 \\ \text { R-7.5 } & \text { Residential dwelling } & 7,500 & 46 \\ \text { R-5 } & \text { Residential dwelling } & 5,000 & 50 \\ \text { M-F } & \text { Multiple-family dwelling } & \text { variable } & 72 \\ \text { SCH } & \text { Schools } & \text { variable } & 35 \\ \text { CH } & \text { Churches } & \text { variable } & 85 \\ \text { C } & \text { Commercial district } & \text { variable } & 85 \\ \text { SC } & \text { Shopping center district } & \text { variable } & 100 \\ \text { IND } & \text { Industrial district } & \text { variable } & 72 \\ \text { FW } & \text { Freeway } & \text { variable } & 100 \\ \text { OL } & \text { Open land l } & \text { variable } & 1\end{array}$

If Open land in rural areas and public parks increased to 1.0 percent to account for roads, drives, and scattered buildings. 
To allow for flow from impervious areas into pervious areas, the impervious area of residential zones was reduced to 65 percent of the total; no reduction was made for nonresidential zones. The basic assumptions were: (1) That an average of 65 percent of the rainfall in residential zones becomes direct runoff in the drainage system, and (2) that 100 percent of the flow from nonresidential zones reaches the drainage system by direct sewering.

\section{Rainfall and Runoff}

Peak discharges were measured at four continuous-record gaging stations and 10 crest-stage partial-record stations. Figure 3 shows the locations of the stream-gaging stations. Table 4 gives an identifying map number, basin name, type of station, and availability of streamflow records.

Rainfall amounts and intensities were recorded at rain gages throughout the area. The locations and designation of the rain gages are shown on figure 3 ; table 4 shows the availability of rainfall records. Table 5 shows the grouping of rain gages and the rainfall-weighting methods used.

\section{Evaporation}

Daily evaporation was used to compute daily potential evapotranspiration, which in conjunction with soil moisture, controls the rate of infiltration and ultimately the amount of rainfall excess that appears as surface runoff.

Monthly sunken-pan evaporation records since January 1917 were available from the Texas Agricultural Experiment Station near Denton, which is 30 miles ( 48.3 kilometers) northwest of Love Field in Dallas. Weather Bureau Class A pan records were available since mid-1953 for another evaporation station located at Grapevine Dam, 18 miles (29.0 kilometers) south of Denton and 14 miles (22.5 kilometers) northwest of Love Field.

For the period of study prior to 1953 (except 1914-16), daily pan evaporation was estimated from monthly records for the Denton station. Daily evaporation for this period was estimated by dividing monthly evaporation by the number of days in each month. For the period 1914-16, prior to the availability of any evaporation data, the average monthly evaporation for the period 1917-53 was used to estimate daily evaporation. After 1953, observed daily pan evaporation at the Grapevine Dam station was used. 
Table 4.--Stream-gaging stations and rain gages in the Dallas metropolitan area

\begin{tabular}{|c|c|c|c|c|c|}
\hline \multicolumn{3}{|c|}{ Stream-gaging station } & \multirow{2}{*}{$\begin{array}{l}\text { Rain } \\
\text { gage } \\
\text { no. } \\
\text { (fig. 3) } \\
\end{array}$} & \multicolumn{2}{|c|}{$\begin{array}{c}\text { Period of record } \\
\text { (water years) }\end{array}$} \\
\hline $\begin{array}{r}\text { Map } \\
\text { no. } \\
(\text { fig. 3) } \\
\end{array}$ & Basin & Type of station & & $\begin{array}{c}\text { Gaging } \\
\text { stations }\end{array}$ & $\begin{array}{l}\text { Rain } \\
\text { gages }\end{array}$ \\
\hline $8-556$ & Joes Creek & Partial record & 1,2 & $1964-70$ & $1964-70$ \\
\hline $8-557$ & Bachman Branch & Continuous record & 1,2 & $1964-70$ & $1964-70$ \\
\hline $8-565$ & Turtle Creek & Continuous record & $1-5$ & $1952-70$ & $1962-70$ \\
\hline $8-570.2$ & Coombs Creek & Partial record & $1 / 1$ & $1965-70$ & $1 / 1969-70$ \\
\hline $8-570.5$ & Cedar Creek & Partial record & $1 / 1$ & $1965-70$ & $1969-70$ \\
\hline $8-571$ & $\begin{array}{l}\text { White Rock Creek above } \\
\text { Keller Springs Road }\end{array}$ & Continuous record & $1-3$ & $1962-70$ & $1962-70$ \\
\hline $8-571.2$ & Spanky Branch & Parital record $2 /$ & $4,5,10$ & $1962-70$ & $1962-70$ \\
\hline $8-571.4$ & Cottonwood Creek & Partial record $3 /$ & $10-12$ & $1962-70$ & $1962-70$ \\
\hline $8-571.6$ & Floyd Branch & Partial record $2 /$ & 11,12 & $1962-70$ & $1962-70$ \\
\hline $8-572$ & $\begin{array}{c}\text { White Rock Creek above } \\
\text { Greenville Avenue }\end{array}$ & Continuous record & $1-12$ & $1962-70$ & $1962-70$ \\
\hline $8-573.2$ & Ash Creek & Partial record $4 /$ & $5 / 14,15$ & $1963-70$ & $1963-70$ \\
\hline $8-573.4$ & Forney Creek & Partial record & 14,15 & $1963-70$ & $1963-70$ \\
\hline $8-574.2$ & Fivemile Creek & Partial record & 2 & $1965-70$ & $1969-70$ \\
\hline $8-574.25$ & Woody Branch & Partial record & 2 & $1965-70$ & $1969-70$ \\
\hline
\end{tabular}

If One rain gage common to stations $8-570.2$ and $8-570.5$; rain gage with intermittent operation at station 8-570.2 since 1965.

2) Crest-stage gage only prior to 1968 .

3/ Crest-stage gage only prior to 1965 .

4) Crest-stage gage only after 1967.

5) Rain gage 15 record started in 1965 . 
Table 5.--Stream-gaging stations, rain gages, rain-gage grouping, and rainfall-weighting methods used in the basins modeled

\begin{tabular}{|c|c|c|c|c|}
\hline $\begin{array}{l}\text { Gaging } \\
\text { station } \\
\text { no. } \\
\text { (fig. 3) }\end{array}$ & Basin & $\begin{array}{l}\text { Number of } \\
\text { subbasin } \\
\text { rain gages } \\
\text { used }\end{array}$ & $\begin{array}{l}\text { Rain gages for storm } \\
\text { period and daily- } \\
\text { rainfall definition } 1 /\end{array}$ & $\begin{array}{l}\text { Rainfall- } \\
\text { weighting } \\
\text { method }\end{array}$ \\
\hline $8-556$ & Toes Creek & 2 & $\left(1-J, 1-B^{*}\right),\left(2-J^{*}\right)$ & Thiessen \\
\hline $8-557$ & Bachman Branch & 2 & $\left(1-B^{*}\right),\left(2-B^{*}, 1-T\right)$ & Thiessen \\
\hline $8-565$ & Turtle Creek & 2 & $\begin{array}{l}\left(1-T^{*}, 2-T, 3-T\right) \\
\left(2-T, 3-T, 4-T^{*},\right. \\
5-T)\end{array}$ & Thiessen \\
\hline $8-570.2$ & Coombs Creek & 1 & 2/ $\left(8-570.2^{* *}\right),(5-T)$ & -- \\
\hline $8-570.5$ & Cedar Creek & 1 & 2f $\left(8-570.2^{*}\right),(14-W)$ & -- \\
\hline $8-571$ & $\begin{array}{l}\text { White Rock Creek above } \\
\text { Keller Springs Road }\end{array}$ & 1 & $\left(1-W, 2-W^{*}, 3-W\right)$ & Average \\
\hline $8-571.2$ & Spanky Branch & 1 & $\left(4-W, 5-W^{*}, 10-W\right)$ & Thiessen \\
\hline $8-571.4$ & Cottonwood Creek & 1 & $\left(10-W, 11-W^{*}, 12-W\right)$ & Thiessen \\
\hline $8-571.6$ & Floyd Branch & 1 & $\left(11-W^{*}, 12-W\right)$ & Thiessen \\
\hline $8-572$ & $\begin{array}{l}\text { White Rock Creek above } \\
\text { Greenville Avenue }\end{array}$ & 1 & (1-W through $12-W) *$ & Average \\
\hline- & $\begin{array}{l}\text { White Rock Creek between } \\
\text { Keller Springs Road and } \\
\text { Greenville Avenue }\end{array}$ & - & (4-W through $12-W)$ & Average \\
\hline $8-573.2$ & Ash Creek & 1 & $\left(14-\mathrm{W}, 15-\mathrm{W}^{*}\right)$ & Thiessen, distance \\
\hline $8-573.4$ & Forney Creek & 1 & $\left(14-W^{*}\right)$ & -- \\
\hline $8-574.2$ & Fivemile Creek & 1 & $\left(2-F^{-*}\right)$ & -- \\
\hline $8-574.25$ & Woody Branch & 1 & $\left(2-F^{*}\right)$ & -- \\
\hline
\end{tabular}

I/ Alphabetic designation with rain-gage number is keyed to location; example, I-J is gage number I in Joes Creek Basin (fig. 2).

2/ Rain gage operated at crest-stage partial-record station.

* Denotes gage used for time distribution of storm-period rainfall within a day and for dailymoisture accounting (single gage, nonweighted) between storm days, except Coombs Creek and Cedar Creek, where gages 5-T and 14-W were used for daily-moisture accounting; White Rock Creek above Greenville Avenue was the average of all available gages. 
Because the pan evaporation at Grapevine Dam was used as input to the model during calibration, it was desirable to use the equivalent for the entire period of peak-discharge simulation (1914-70). Ratios of monthly evaporation as measured at Grapevine Dam and at Denton were defined from concurrent periods of observation. The ratios varied from 1.25 in December and January to 1.85 . for May through July. These ratios were applied to the records for Denton from January 1917 to October 1953.

\section{Distance-Area Curves}

The shape of the runoff hydrograph is dependent upon storage characteristics and travel time. The routing procedure in the hydrologic model transforms rainfall excess from drainage-area increments into discharge by application of proper travel time and reservoir delay.

Travel time was assumed to be proportional to distance. Isochronal lines representing varying travel times were drawn on maps as simple arcs with varying radii, with some weight given to abrupt changes in the shape of the basins and directions of the channe1. The effects of storm sewering on travel time were not investigated. Isochronal subareas were measured, accumulated, and plotted against channel distances to derive the distance-area curves.

\section{COMPARISON OF OBSERVED AND COMPUTED PEAK DISCHARGES}

Observed peak discharges and flood volumes were compared with those computed by the hydrologic model to determine if the model produced reasonable results. Both the observed and computed data are given in table 6. The results are shown graphically as scatter diagrams for the control basins (those for which observed flood-volume data were available to derive moisture-accounting parameters) and noncontrol basins (those in which moisture-accounting parameters were estimated from the parameters derived for the control basins) in figures 4 and 5 , respectively.

For the control basins, the average standard error for simulated flood peaks is 26 percent; for the noncontrol basins, the average standard error for the simulated flood peaks is 46 percent.

\section{EXTENSION OF FLOOD RECORDS IN TIME AT GAGING STATIONS}

The long-term rainfall records collected by the National Weather Service since 1914 at Dallas and nearby long-term records of measured or estimated pan evaporation were used as input to the hydrologic model to 
OBSERVED PEAK DISCHARGE, IN CUBIC METERS PER SECOND

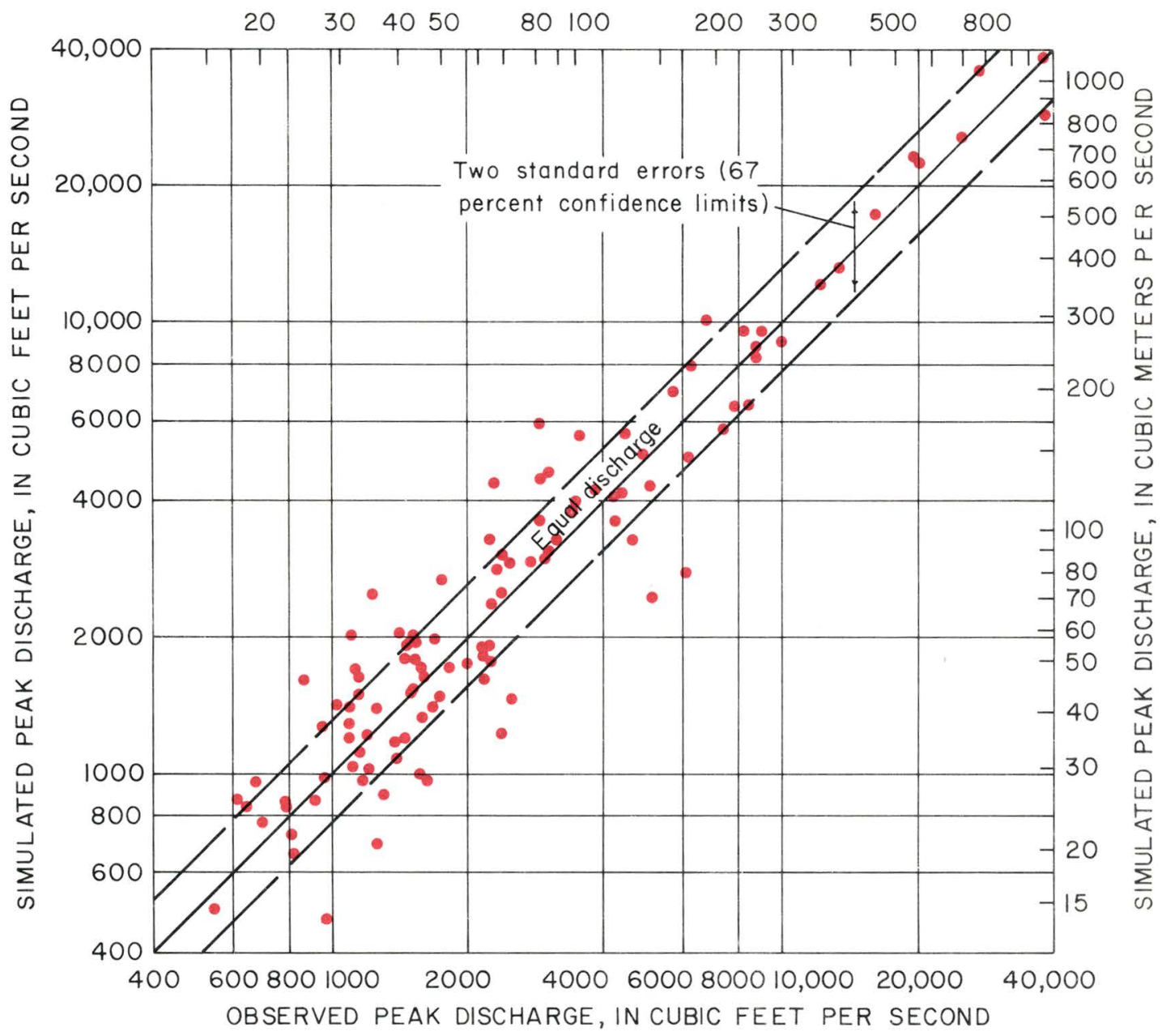


OBSERVED PEAK DISCHARGE, IN CUBIC METERS PER SECOND

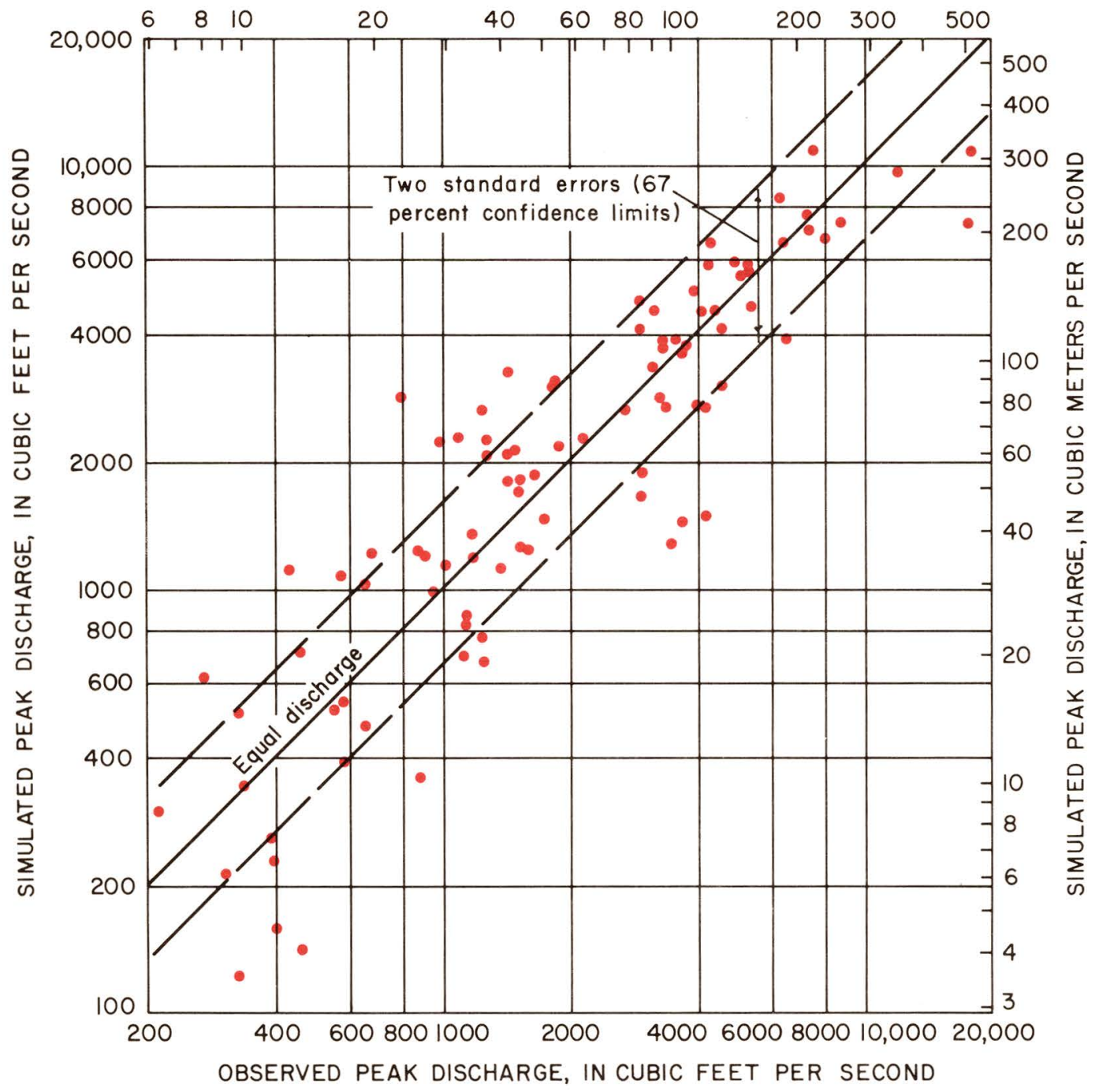


Table 6.--Storm rainfall and discharge data for Dallas

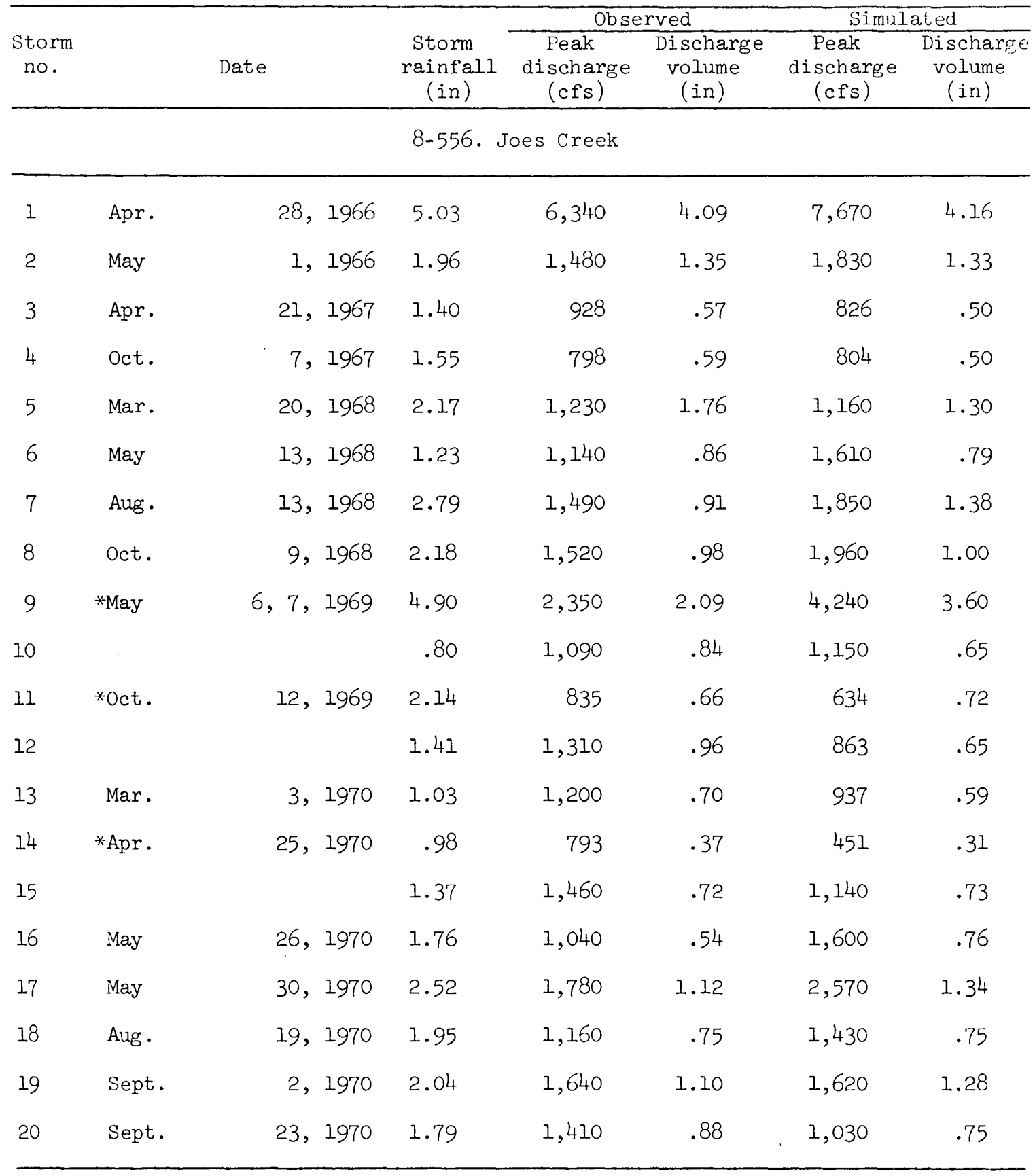

Note: For stations 8-556, 8-557, 8-565, 8-570.2, 8-571, and 8-572, observed and simulated discharge data do not include estimated base flow; for other stations, observed discharge data include base flow, and simulated discharge data do not. Asterisk denotes analysis as a complex storm. 
Table 6.--Storm rainfall and discharge data for l)allas--cuntindad

\begin{tabular}{|c|c|c|c|c|c|c|}
\hline \multirow[b]{2}{*}{$\begin{array}{c}\text { Storm } \\
\text { no. }\end{array}$} & \multirow[b]{2}{*}{ Date } & \multirow[b]{2}{*}{$\begin{array}{l}\text { Storm } \\
\text { rainfall } \\
\text { (in) }\end{array}$} & \multicolumn{2}{|c|}{ Observed } & \multicolumn{2}{|c|}{ Simulated } \\
\hline & & & $\begin{array}{c}\text { Peak } \\
\text { discharge } \\
\text { (cfs) }\end{array}$ & $\begin{array}{l}\text { Discharge } \\
\text { volume } \\
\text { (in) }\end{array}$ & $\begin{array}{c}\text { Peak } \\
\text { discharge } \\
\text { (cfs) }\end{array}$ & $\begin{array}{c}\text { Discharge } \\
\text { volume } \\
\text { (in) }\end{array}$ \\
\hline
\end{tabular}

8-557. Bachman Branch

\begin{tabular}{|c|c|c|c|c|c|c|c|}
\hline 1 & Sept. & 22,1964 & 1.63 & 3,030 & 1.01 & 2,990 & 0.98 \\
\hline 2 & Feb. & $8,9,1965$ & 3.15 & 1,650 & 1.60 & 933 & 1.02 \\
\hline 3 & *May & 10,1965 & 1.89 & 2,030 & .58 & 1,690 & .56 \\
\hline 4 & & & 2.27 & 5,070 & 1.68 & 4,150 & 1.08 \\
\hline 5 & Feb. & 9, 1966 & 2.05 & 709 & .54 & 742 & .50 \\
\hline 6 & Apr & 28, 1966 & 5.21 & 16,000 & 4.41 & 16,900 & 4.74 \\
\hline 7 & *June & 17,1966 & 1.53 & 1,100 & .32 & 1,340 & .45 \\
\hline 8 & & & .34 & 560 & .10 & 472 & .12 \\
\hline 9 & Oct. & 4, 1966 & 1.45 & 684 & .26 & 901 & .35 \\
\hline 10 & May & 31, 1967 & 1.63 & 819 & .43 & 697 & .43 \\
\hline 11 & oct. & 7,1967 & 1.52 & 869 & .25 & 1,530 & .43 \\
\hline 12 & Mar. & 20,1968 & 1.96 & 1,630 & 1.51 & 1,580 & 1.27 \\
\hline 13 & May & 13, 1968 & 1.14 & 1,600 & .58 & 1,270 & .36 \\
\hline 14 & June & 24,1968 & 1.91 & 1,170 & .53 & 1,060 & .50 \\
\hline 15 & Oct. & 9, 1968 & 1.81 & 1,240 & $\cdot 38$ & 2,400 & .60 \\
\hline 16 & *May & $6,7,1969$ & 5.16 & 8,350 & 2.89 & 8,070 & 3.05 \\
\hline 17 & & & .72 & 1,120 & .34 & 1,940 & .45 \\
\hline 18 & *Apr. & 25,1970 & .96 & 967 & .22 & 941 & .29 \\
\hline 19 & , & & 1.41 & 2,820 & .76 & 2,840 & .74 \\
\hline
\end{tabular}


Table 6.--Storm rainfall and discharge data for Dallas--Continued

\begin{tabular}{|c|c|c|c|c|c|c|c|c|c|}
\hline \multirow[b]{2}{*}{$\begin{array}{c}\text { Storm } \\
\text { no. }\end{array}$} & \multirow{2}{*}{\multicolumn{4}{|c|}{ Date }} & \multicolumn{3}{|c|}{ Observed } & \multicolumn{2}{|c|}{ Simulated } \\
\hline & & & & & $\begin{array}{c}\text { Storm } \\
\text { rainfal1 } \\
\text { (in) }\end{array}$ & $\begin{array}{c}\text { Peak } \\
\text { discharge } \\
\text { (cfs) }\end{array}$ & $\begin{array}{l}\text { Discharge } \\
\text { volume } \\
\text { (in) }\end{array}$ & $\begin{array}{c}\text { Peak } \\
\text { discharge } \\
\text { (cfs) }\end{array}$ & $\begin{array}{l}\text { Discharge } \\
\text { volume } \\
\text { (in) }\end{array}$ \\
\hline \multicolumn{10}{|c|}{ 8-565. Turtle Creek } \\
\hline 1 & Apr. & & 30 & 1962 & 1.68 & 3,040 & 0.94 & 4,490 & 1.03 \\
\hline 2 & July & & 27 & 1962 & 4.47 & 4,630 & 2.29 & 5,200 & 2.26 \\
\hline 3 & Apr. & & 28 & 1963 & 1.99 & 4,280 & 1.89 & 3,490 & 1.29 \\
\hline 4 & June & & 16 & 1963 & 1.38 & 1,160 & .35 & 1,560 & .52 \\
\hline 5 & Feb. & & & 1966 & 2.18 & 1,280 & .87 & 1,350 & .81 \\
\hline 6 & *Apr. & 28 & 29, & 1966 & 3.77 & 12,200 & 3.77 & 12,000 & 3.28 \\
\hline 7 & & & & & 1.04 & 2,350 & 1.04 & 2,740 & .73 \\
\hline 8 & & & & & .99 & 2,010 & .99 & 2,640 & .75 \\
\hline 9 & sune & & 17 & 1966 & 1.36 & 966 & .42 & 1,220 & .51 \\
\hline 10 & Apr. & & 21 , & 1967 & 1.61 & 1,700 & .61 & 1,410 & .61 \\
\hline 11 & Anr. & & 22 , & 1968 & 1.20 & 2,250 & .53 & 1,850 & .46 \\
\hline 12 & May & & 13 & 1968 & 1.46 & 3,210 & .85 & 3,180 & .87 \\
\hline 13 & June & & 24, & 1968 & 2.31 & 1,540 & .81 & 1,460 & .88 \\
\hline 14 & oct. & & & 1968 & 1.53 & 1,540 & .47 & 1,870 & .58 \\
\hline 15 & *Jan. & 29 & 30 & 1969 & 1.57 & 2,150 & .59 & 1,830 & .58 \\
\hline 16 & & & & & .69 & 1,230 & .34 & 985 & .27 \\
\hline 17 & May & 4 & 5 , & 1969 & 2.37 & 2,200 & 1.03 & 1,740 & .95 \\
\hline 18 & May & 6 &, 7 , & 1969 & 5.59 & 8,830 & 4.44 & 8,530 & 4.73 \\
\hline 19 & *Apr. & & 25 , & 1970 & .88 & 623 & .24 & 838 & .32 \\
\hline 20 & & & & & 1.20 & 2,430 & .73 & 1,190 & .50 \\
\hline 21 & Aug. & & 19, & 1970 & 1.85 & 1,420 & .42 & 1,960 & .70 \\
\hline
\end{tabular}


Table 6.--Storm rainfall and discharge data for Dallas--Continued

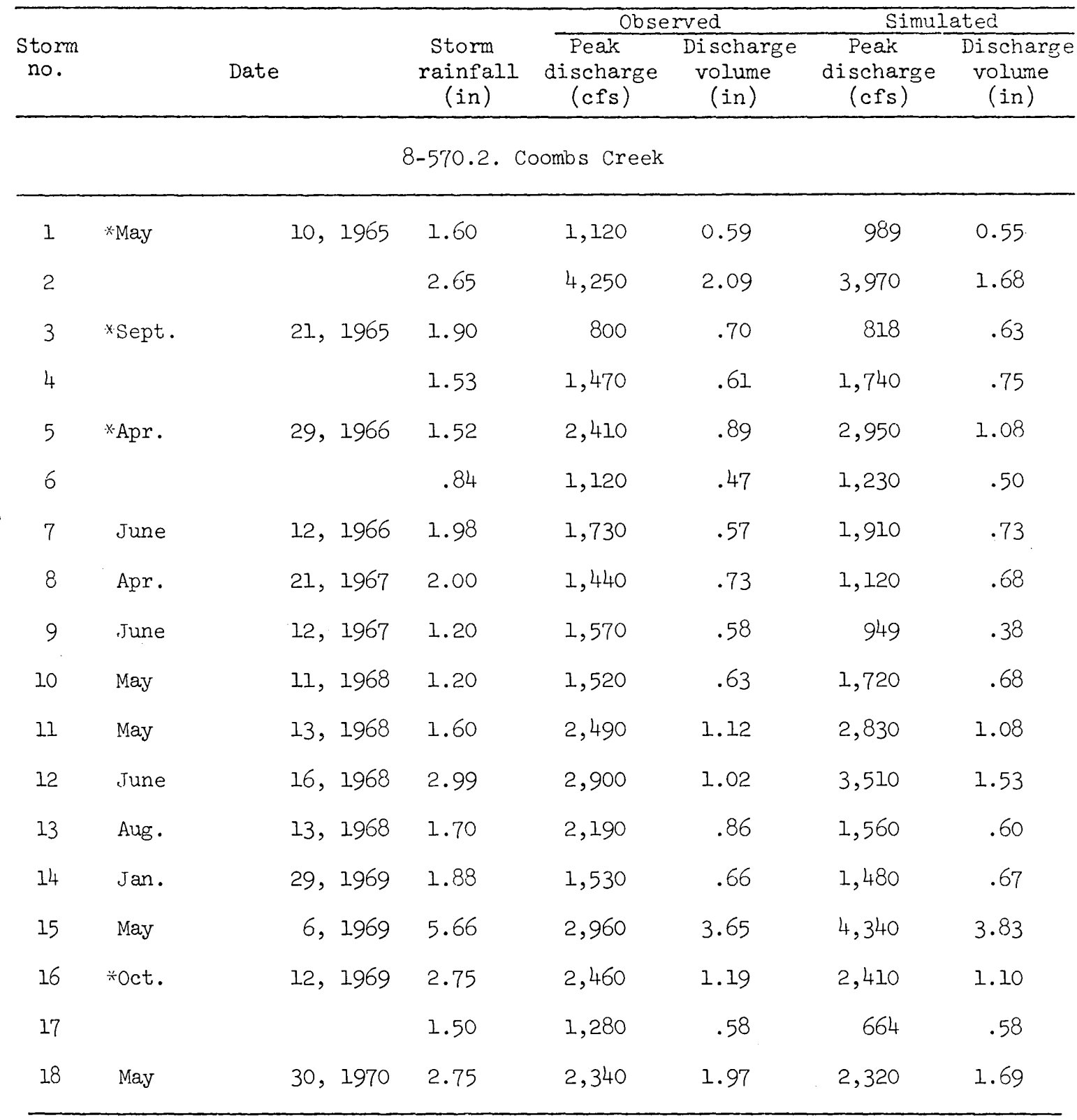


Table 6.--Storm rainfall and discharge data for Dallas--Continued

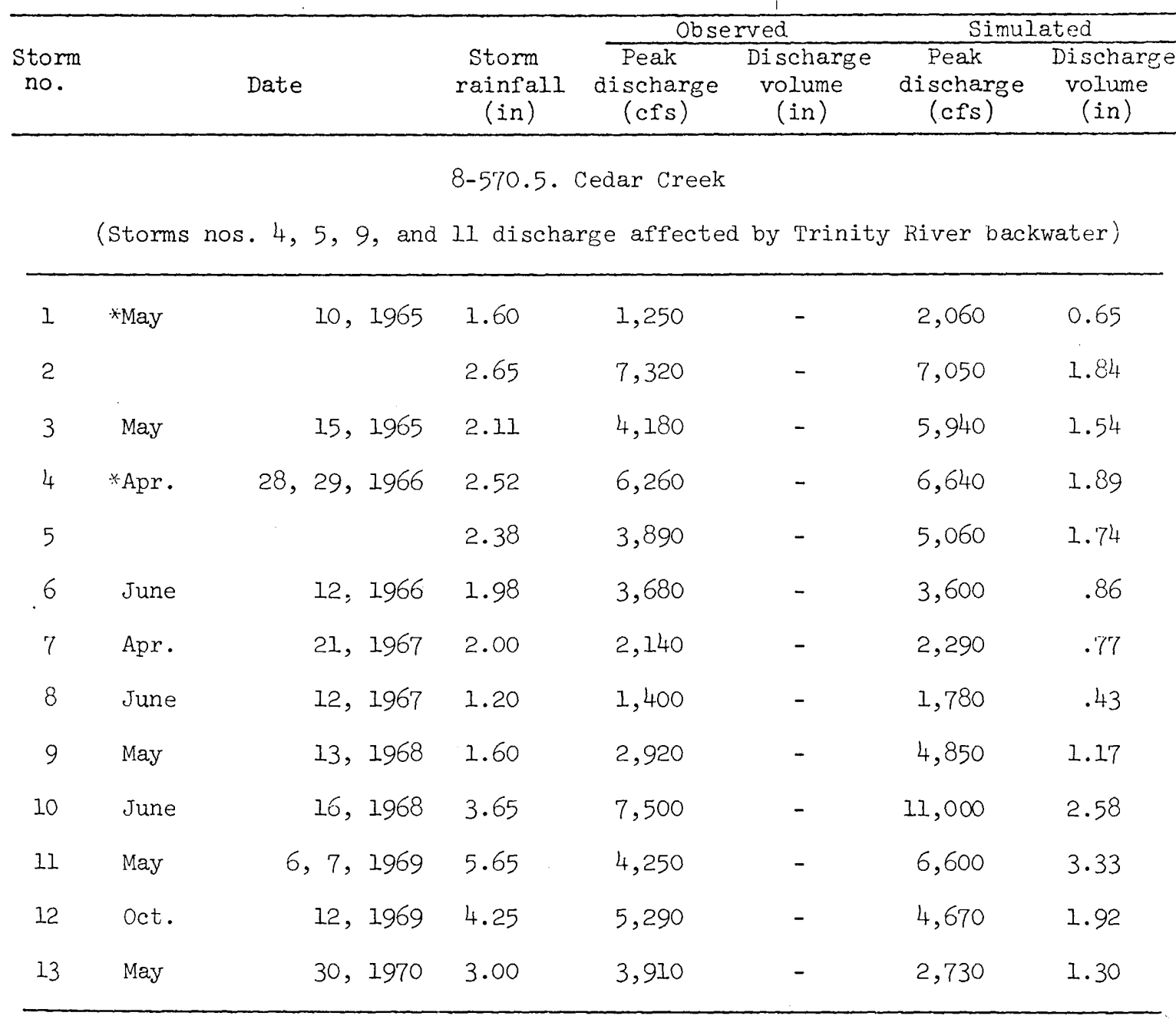


Table 6.--Storm rainfall and discharge data for Dallas--Continued

\begin{tabular}{|c|c|c|c|c|c|c|}
\hline \multirow[b]{2}{*}{$\begin{array}{c}\text { Storm } \\
\text { no. }\end{array}$} & \multirow[b]{2}{*}{ Date } & \multirow[b]{2}{*}{$\begin{array}{c}\text { Storm } \\
\text { rainfall } \\
\text { (in) }\end{array}$} & \multicolumn{2}{|c|}{ Observed } & \multicolumn{2}{|c|}{ Simulated } \\
\hline & & & $\begin{array}{c}\text { Peak } \\
\text { discharge } \\
\text { (cfs) }\end{array}$ & $\begin{array}{l}\text { Discharge } \\
\text { volume } \\
\text { (in) }\end{array}$ & $\begin{array}{c}\text { Peak } \\
\text { discharge } \\
\text { (cfs) }\end{array}$ & $\begin{array}{l}\text { Discharge } \\
\text { volume } \\
\text { (in) }\end{array}$ \\
\hline
\end{tabular}

8-571. White Rock Creek above Keller Springs Road

(Records for storm no. 1 partly estimated)

\begin{tabular}{|c|c|c|c|c|c|c|c|c|c|}
\hline 1 & Sept. & 20 & 21 & 1964 & 14.12 & 37,900 & 11.23 & 28,400 & 12.09 \\
\hline 2 & Sept. & & 27 , & 1964 & 1.81 & 3,450 & .81 & 3,690 & .74 \\
\hline 3 & May & & 10 & 1965 & 3.54 & 5,710 & 1.09 & 6,820 & 1.26 \\
\hline 4 & May & & 27 , & 1965 & 2.39 & it, 560 & .95 & 5,460 & 1.06 \\
\hline 5 & *Apr. & 28 & 29, & 1966 & 4.15 & 9,000 & 2.67 & 9,200 & 3.18 \\
\hline 6 & & & & & 2.77 & 7,900 & 2.25 & 6,280 & 1.72 \\
\hline 7 & Apr. & & 25, & 1967 & 1.13 & 1,710 & .24 & 1,350 & .23 \\
\hline 8 & Mar. & & 20 , & 1968 & 3.56 & 6,200 & 2.26 & 4,870 & 1.66 \\
\hline 9 & June & & 24 & 1968 & 1.74 & 653 & .16 & 802 & .15 \\
\hline 10 & Jan. & 29 , & 30 , & 1969 & 2.34 & 1,860 & .49 & 1,660 & .44 \\
\hline 11 & May & 6 , & , 7, & 1969 & 3.45 & 8,280 & 1.82 & 9,270 & 2.04 \\
\hline 12 & May & & 17 , & 1969 & 1.89 & 3,590 & .84 & 5,450 & .95 \\
\hline 13 & May & & 26 , & 1969 & 1.27 & 3,000 & .40 & 2,880 & .47 \\
\hline 14 & Apr. & & 25, & 1970 & 2.77 & 4,930 & .91 & 4,910 & .90 \\
\hline 15 & June & & 1 , & 1970 & 1.37 & 3,590 & .57 & 3,880 & .69 \\
\hline
\end{tabular}


Table 6.--Storm rainfall and discharge data for Dallas--Continued

\begin{tabular}{|c|c|c|c|c|c|c|c|}
\hline \multirow[b]{2}{*}{$\begin{array}{l}\text { Storm } \\
\text { no. }\end{array}$} & \multirow{2}{*}{\multicolumn{2}{|c|}{ Date }} & \multirow[b]{2}{*}{$\begin{array}{c}\text { Storm } \\
\text { rainfall } \\
\text { (in) }\end{array}$} & \multicolumn{2}{|c|}{ Observed } & \multicolumn{2}{|c|}{ Simulated } \\
\hline & & & & $\begin{array}{c}\text { Peak } \\
\text { discharge } \\
\text { (cfs) }\end{array}$ & $\begin{array}{l}\text { Discharge } \\
\text { volume } \\
\text { (in) }\end{array}$ & $\begin{array}{c}\text { Peak } \\
\text { discharge } \\
\text { (cfs) }\end{array}$ & $\begin{array}{c}\text { Discharge } \\
\text { volume } \\
\text { (in) }\end{array}$ \\
\hline & \multicolumn{5}{|c|}{ 8-571.2. Spanky Branch } & $\cdot$ & \\
\hline 1 & Sept. & 27,1962 & $7 \cdot 35$ & 4,020 & - & 4,570 & 3.87 \\
\hline 2 & Sept. & $7,8,1962$ & 2.58 & 1,410 & - & 2,080 & 1.36 \\
\hline 3 & Oct. & 8, 1962 & 3.60 & 2,880 & - & 4,190 & 2.02 \\
\hline 4 & Oct. & 28,1962 & 3.48 & 1,340 & - & 1,120 & 1.02 \\
\hline 5 & Sept. & $20,21,1964$ & 11.78 & 7,870 & - & 6,790 & 9.93 \\
\hline 6 & Feb. & $8,9,1964$ & 3.45 & 1,120 & - & 836 & .81 \\
\hline 7 & May & 10,1965 & 4.65 & 2,670 & - & 2,670 & 1.95 \\
\hline 8 & Apr. & $28,29,1966$ & 8.23 & 5,000 & - & 5,550 & 5.91 \\
\hline 9 & May & $30,31,1967$ & 3.00 & 635 & - & 479 & .49 \\
\hline 10 & Mar. & $19,20,1968$ & 3.72 & 1,500 & - & 1,270 & 1.62 \\
\hline 11 & May & 11,1968 & .87 & 424 & - & 718 & .31 \\
\hline 12 & May & $6,7,1969$ & 4.20 & 3,680 & - & 3,710 & 2.74 \\
\hline 13 & May & 26, 1969 & .91 & 869 & - & 357 & .16 \\
\hline 14 & Apr. & 25,1970 & 2.60 & 1,630 & - & 1,880 & .95 \\
\hline
\end{tabular}


Table 6.--Storm rainfall and discharge data for Dallas--Continued

\begin{tabular}{|c|c|c|c|c|c|c|}
\hline \multirow[b]{2}{*}{$\begin{array}{c}\text { Storm } \\
\text { no. }\end{array}$} & \multirow[b]{2}{*}{ Date } & \multirow[b]{2}{*}{$\begin{array}{l}\text { Storm } \\
\text { rainfall } \\
\text { (in) }\end{array}$} & \multicolumn{2}{|c|}{ Observed } & \multicolumn{2}{|c|}{ Simulated } \\
\hline & & & $\begin{array}{c}\text { Peak } \\
\text { discharge } \\
\text { (cfs) }\end{array}$ & $\begin{array}{l}\text { Discharge } \\
\text { volume } \\
\text { (in) }\end{array}$ & $\begin{array}{c}\text { Peak } \\
\text { discharge } \\
\text { (cfs) }\end{array}$ & $\begin{array}{l}\text { Discharge } \\
\text { volume } \\
\text { (in) }\end{array}$ \\
\hline
\end{tabular}

8-571.4 Cottonwood Creek

\begin{tabular}{|c|c|c|c|c|c|c|c|c|c|}
\hline 1 & June & & 25 & 1962 & 2.51 & 794 & - & 2,840 & 0.97 \\
\hline 2 & July & & 27 & 1962 & 5.95 & 5,090 & - & 5,600 & 3.68 \\
\hline 3 & oct. & & 8 & 1962 & 5.80 & 17,400 & - & 7,270 & 3.15 \\
\hline 4 & July & & 14 , & 1963 & 2.28 & 657 & - & 1,220 & .64 \\
\hline 5 & Sept. & 20 & 21 & 1964 & 8.59 & 6,200 & - & 8,460 & 6.13 \\
\hline 6 & Feb. & & , 9, & 1965 & 3.70 & 1,180 & - & 789 & 1.06 \\
\hline 7 & May & & 10 & 1965 & 4.65 & 4,490 & - & 3,010 & 1.88 \\
\hline 8 & Apr. & 28 & 29, & 1966 & 9.81 & 17,600 & - & 10,800 & 7.73 \\
\hline 9 & June & & 12 , & 1966 & 1.58 & 421 & - & 1,150 & .43 \\
\hline 10 & May & 19 & 20 & 1967 & 2.03 & 2,880 & - & 1,650 & .62 \\
\hline 11 & June & & 12 , & 1967 & 1.30 & 562 & - & 1,100 & .36 \\
\hline 12 & Mar. & 19 & 20 & 1968 & 3.35 & 890 & - & 1,200 & 1.25 \\
\hline 13 & Aug. & & 13 & 1968 & 2.82 & 1,380 & - & 3,210 & 1.16 \\
\hline 14 & May & & , 7 & 1969 & 4.14 & 4,530 & - & 4,150 & 2.64 \\
\hline 15 & May & & 17 , & 1969 & 1.57 & 640 & - & 1,030 & .49 \\
\hline 16 & Apr. & & 25 , & 1970 & 2.59 & 1,480 & - & 1,830 & .97 \\
\hline 17 & May & & 30 & 1970 & 3.27 & 3,260 & - & 3,900 & 1.44 \\
\hline
\end{tabular}


Table 6.--Storm rainfall and discharge data for Dallas--Continued

\begin{tabular}{|c|c|c|c|c|c|c|c|}
\hline \multirow[b]{2}{*}{$\begin{array}{l}\text { Storm } \\
\text { no. }\end{array}$} & \multirow{2}{*}{\multicolumn{2}{|c|}{ Date }} & & \multicolumn{2}{|c|}{ Observed } & \multicolumn{2}{|c|}{ Simulated } \\
\hline & & & $\begin{array}{l}\text { Storm } \\
\text { rainfall } \\
\text { (in) }\end{array}$ & $\begin{array}{c}\text { Peak } \\
\text { discharge } \\
\text { (cfs) }\end{array}$ & $\begin{array}{l}\text { Discharge } \\
\text { volume } \\
\text { (in) }\end{array}$ & $\begin{array}{c}\text { Peak } \\
\text { discharge } \\
\text { (cfs) }\end{array}$ & $\begin{array}{l}\text { Discharge } \\
\text { volume } \\
\text { (in) }\end{array}$ \\
\hline \multicolumn{8}{|c|}{ 8-571.6. Floyd Branch } \\
\hline 1 & June & 25,1962 & 3.12 & 1,770 & - & 3,030 & 1.89 \\
\hline 2 & July & 27,1962 & 5.37 & 3,200 & - & 2,840 & 3.41 \\
\hline 3 & oct. & 8, 1962 & 6.68 & 4,850 & - & 5,970 & 4.67 \\
\hline 4 & Sept. & $20,21,1964$ & 7.80 & 3,500 & - & 3,890 & 4.94 \\
\hline 5 & Feb. & $8,9,1965$ & $3: 76$ & 1,220 & - & 676 & 1.52 \\
\hline 6 & May & 10,1965 & 4.75 & 2,880 & - & 1,890 & 2.07 \\
\hline 7 & Apr & $28,29,1966$ & 10.61 & 8,580 & - & 7,390 & 9.68 \\
\hline 8 & May & $19,20,1967$ & 2.15 & 1,000 & - & 1,150 & .78 \\
\hline 9 & Mar. & $19,20,1968$ & 3.00 & 1,110 & - & 699 & 1.27 \\
\hline 10 & Aug. & 13,1968 & 2.94 & 965 & - & 2,220 & 1.44 \\
\hline 11 & May & $6,7,1969$ & 4.07 & 3,350 & - & 2,730 & 3.16 \\
\hline 12 & Apr. & 25,1970 & 2.68 & 1,700 & - & 1,460 & 1.33 \\
\hline 13 & May & 30,1970 & 3.92 & 3,100 & - & 3,360 & 2.20 \\
\hline
\end{tabular}


Table 6.--Storm rainfall and discharge data for Dallas--Continued

\begin{tabular}{|c|c|c|c|c|c|c|}
\hline \multirow[b]{2}{*}{$\begin{array}{c}\text { Storm } \\
\text { no. }\end{array}$} & \multirow[b]{2}{*}{ Date } & \multirow[b]{2}{*}{$\begin{array}{l}\text { Storm } \\
\text { rainfall } \\
\text { (in) }\end{array}$} & \multicolumn{2}{|c|}{ observed } & \multicolumn{2}{|c|}{ Simulated } \\
\hline & & & $\begin{array}{c}\text { Peak } \\
\text { discharge } \\
\text { (cfs) }\end{array}$ & $\begin{array}{l}\text { Discharge } \\
\text { volume } \\
\text { (in) }\end{array}$ & $\begin{array}{c}\text { Peak } \\
\text { discharge } \\
\text { (cfs) }\end{array}$ & $\begin{array}{c}\text { Discharge } \\
\text { volume } \\
\text { (in) }\end{array}$ \\
\hline
\end{tabular}

8-572. White Rock Creek above Greenville Avenue

\begin{tabular}{|c|c|c|c|c|c|c|c|c|}
\hline 1 & Nov. & & 22,1961 & 1.83 & 2,920 & 0.25 & 5,770 & 0.54 \\
\hline 2 & July & & 27, 1962 & 6.22 & $? 0,000$ & 3.69 & 22,000 & 2.86 \\
\hline 3 & oct. & & 8, 1962 & 4.51 & 24,500 & 1.77 & 25,700 & 2.66 \\
\hline 4 & Sept. & 20 & 21,1964 & 11.07 & 38,100 & 8.24 & 38,700 & 7.18 \\
\hline 5 & Sept. & & 27,1964 & 1.52 & 6,820 & .75 & 9,910 & 1.17 \\
\hline 6 & *May & & 10, 1965 & 1.53 & 4,420 & .20 & 4,020 & .34 \\
\hline 7 & & & & 2.84 & 13,400 & 1.70 & 12,500 & 1.33 \\
\hline 8 & Apr. & & 28, 1966 & 4.97 & 26,900 & 3.19 & 36,000 & 4.18 \\
\hline 9 & *May & 30 & 31,1967 & 1.33 & 2,850 & .16 & 1,700 & .16 \\
\hline 10 & & & & 1.81 & 6,250 & .87 & 2,660 & $\cdot 35$ \\
\hline 11 & Mar. & & 20,1968 & 2.20 & 9,960 & 1.85 & 8,840 & 1.45 \\
\hline 12 & June & & 24,1968 & 1.92 & 2,260 & .28 & 3,190 & .34 \\
\hline 13 & Aug. & & 13,1968 & 2.40 & 8,390 & .42 & 6,320 & .55 \\
\hline 14 & Jan. & & 30, 1969 & .84 & 2,550 & .37 & 1,410 & .11 \\
\hline 15 & May & & 7, 1969 & 4.12 & 19,500 & 3.66 & 22,500 & 3.06 \\
\hline 16 & May & & 17,1969 & 1.58 & 7,440 & .96 & 5,630 & .63 \\
\hline 17 & May & & 26,1969 & 1.05 & 3,890 & .33 & 4,060 & .34 \\
\hline 18 & June & & 1, 1970 & .84 & 5,200 & .45 & 2,360 & .24 \\
\hline
\end{tabular}


Table 6.--Storm rainfall and discharge data for Dallas--Continued

\begin{tabular}{|c|c|c|c|c|c|c|c|}
\hline \multirow[b]{2}{*}{$\begin{array}{c}\text { Storm } \\
\text { no. }\end{array}$} & & \multirow[b]{2}{*}{ Date } & \multirow[b]{2}{*}{$\begin{array}{l}\text { Storm } \\
\text { rainfal1 } \\
\text { (in) }\end{array}$} & \multicolumn{2}{|c|}{ Observed } & \multicolumn{2}{|c|}{ Simulated } \\
\hline & & & & $\begin{array}{c}\text { Peak } \\
\text { discharge } \\
\text { (cfs) }\end{array}$ & $\begin{array}{l}\text { Discharge } \\
\text { volume } \\
\text { (in) }\end{array}$ & $\begin{array}{c}\text { Peak } \\
\text { discharge } \\
\text { (cfs) }\end{array}$ & $\begin{array}{l}\text { Discharge } \\
\text { volume } \\
\text { (in) }\end{array}$ \\
\hline \multicolumn{8}{|c|}{ 8-573.2. Ash Creek } \\
\hline 1 & Feb. & $8,9,1965$ & 3.56 & 1,500 & - & 1,710 & 1.63 \\
\hline 2 & May & $10,1.965$ & 3.60 & 3,570 & - & 1,440 & 1.52 \\
\hline 3 & Apr. & $28,29,1966$ & 7.08 & 5,190 & - & 5,860 & 6.54 \\
\hline 4 & Apr. & 21, 1967 & 1.96 & 3,370 & - & 1,280 & .66 \\
\hline 5 & Mar. & 20,1968 & 1.67 & 1,150 & - & 1,340 & .93 \\
\hline 6 & Apr. & 28,1968 & 1.03 & 1,540 & - & 1,250 & .53 \\
\hline 7 & May & 13, 1968 & 1.18 & 1,430 & - & 2,110 & .85 \\
\hline 8 & May & $6,7,1969$ & 5.20 & 4,330 & - & 4,520 & 3.09 \\
\hline 9 & oct. & 12, 1969 & 2.68 & 850 & - & 1,220 & .94 \\
\hline 10 & Feb. & 24,1970 & 1.58 & 576 & - & 390 & .61 \\
\hline 11 & Apr. & 25,1970 & 1.78 & 1,150 & - & 1,190 & .74 \\
\hline 12 & May & 30,1970 & 2.68 & 1,240 & - & 2,250 & 1.24 \\
\hline 13 & Sept. & $1,2,1970$ & 2.44 & 927 & - & 984 & .83 \\
\hline
\end{tabular}


Table 6.--Storm rainfall and discharge data for Dallas--Continued

\begin{tabular}{|c|c|c|c|c|c|c|}
\hline \multirow[b]{2}{*}{$\begin{array}{c}\text { Storm } \\
\text { no. }\end{array}$} & \multirow[b]{2}{*}{ Date } & \multirow[b]{2}{*}{$\begin{array}{l}\text { Storm } \\
\text { rainfall } \\
\text { (in) }\end{array}$} & \multicolumn{2}{|c|}{ Observed } & \multicolumn{2}{|c|}{ Simulated } \\
\hline & & & $\begin{array}{c}\text { Peak } \\
\text { discharge } \\
\text { (cfs) }\end{array}$ & $\begin{array}{l}\text { Discharge } \\
\text { volume } \\
\text { (in) }\end{array}$ & $\begin{array}{c}\text { Peak } \\
\text { discharge } \\
\text { (cfs) }\end{array}$ & $\begin{array}{l}\text { Discharge } \\
\text { volume } \\
\text { (in) }\end{array}$ \\
\hline
\end{tabular}

8-573.4. Forney Creek

\begin{tabular}{llrlllll}
1 & Feb. & $8,9,1965$ & 3.00 & 390 & - & 230 & 0.65 \\
2 & May & 10,1965 & 3.16 & 566 & - & 539 & 1.20 \\
3 & Apr. & $28,29,1966$ & 5.05 & 1,090 & - & 2,260 & 3.89 \\
4 & Apr. & 21,1967 & 1.99 & 200 & - & 300 & .42 \\
5 & Mar. & 20,1968 & 1.21 & 394 & - & 159 & .38 \\
6 & May & 11,1968 & 1.40 & 268 & - & 625 & .54 \\
7 & May & $6,7,1969$ & 4.22 & 1,130 & - & 845 & 1.80 \\
8 & Apr. & 25,1970 & 1.60 & 318 & - & 511 & .52 \\
9 & May & 30,1970 & 3.09 & 542 & - & 521 & .98 \\
10 & Sept. & $1,2,1970$ & 2.46 & 450 & - & 141 & .37 \\
\hline
\end{tabular}


Table 6.--Storm rainfall and discharge data for Dallas--Conclucied

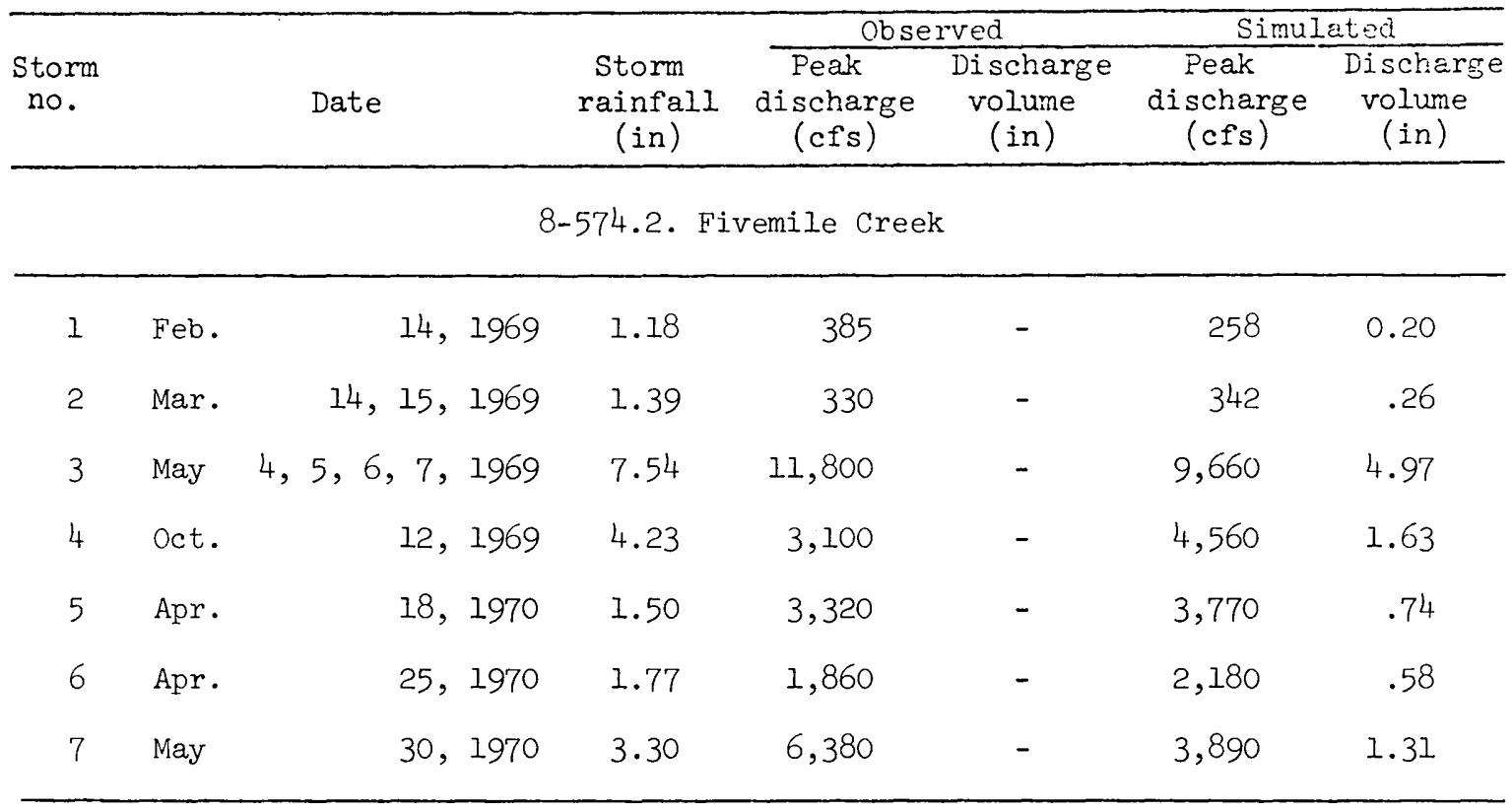

8-574.25. Woody Branch

1 Feb.

14,1969

1.18

318

123

.11

2 Mar.

14, 15, 1969

1.39

300

211

.15

3 May 4, 5, 6, 7, $1969 \quad 7.54$

7,160

7,760

4.72

4 Oct.

12, 1969

4.23

1,810

3,050

1.38

5 Apr.

18,1970

1.50

1,220

2,620

.67

6 Apr.

25,1970

1.77

4,120

1,470

.46

7 May

30,1970

3.30

4,060

2,770

1.12 
compute annual peak discharges at 14 stations. Data for the storms for which the flood peaks were computed are given in table 7. Table 8 summarizes the peak discharges computed from the model and gives the rank of each annual peak at each site.

Flood-frequency characteristics for streams in Dallas were defined by fitting the log-Pearson Type III probability distribution to the 57year (1914-70) simulated annual-peak discharges for each of the 14 gaging stations. In the log-Pearson method, peak discharges for selected recurrence intervals are computed by the equation

$$
\log \mathrm{Q}_{\mathrm{T}}=\mathrm{M}+\mathrm{KS}
$$

where

$\mathrm{Q}_{\mathrm{T}}=$ the peak discharge for a selected recurrence interval $(\mathrm{T})$ in years;

$M=$ the mean of the logarithms of the annual peaks;

$\mathrm{K}=\mathrm{a}$ Pearson Type III frequency factor expressed in number of standard deviations from the mean; and

$S=$ the standard deviation of the logarithms of the annual peaks.

Table 9 gives 7 T-year (recurrence interval) discharges and statistics obtained from fitting the log-Pearson Type III distribution to simulated annual peak-discharge data for each of the 14 gaging stations. Figures 6 and 7 show the flood-frequency curves plotted by using logarithmicprobability scales.

To ensure that the derived log-Pearson Type III frequency curves fit the observed short-term data, each observed annual peak discharge was plotted at its T-year value, computed from

$$
T=\frac{n+1}{m}
$$

where

$$
\begin{aligned}
& \mathrm{n}=\text { the number of years of record; and } \\
& \mathrm{m}=\text { the numerical rank of the peak discharge. }
\end{aligned}
$$




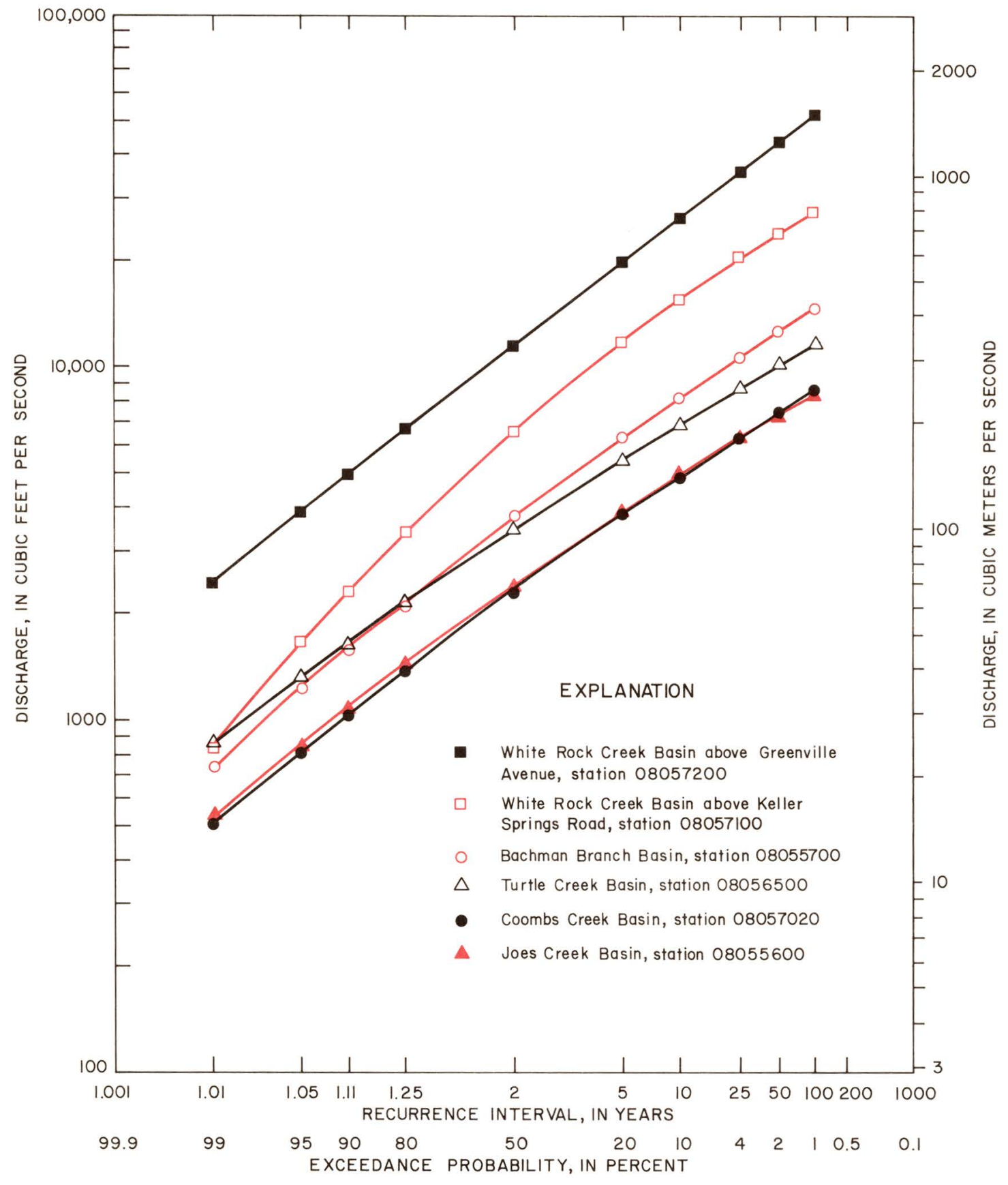

FIGURE 6. - Flood-frequency curves for six gaging stations based on simulated peak discharges for 1914-70 


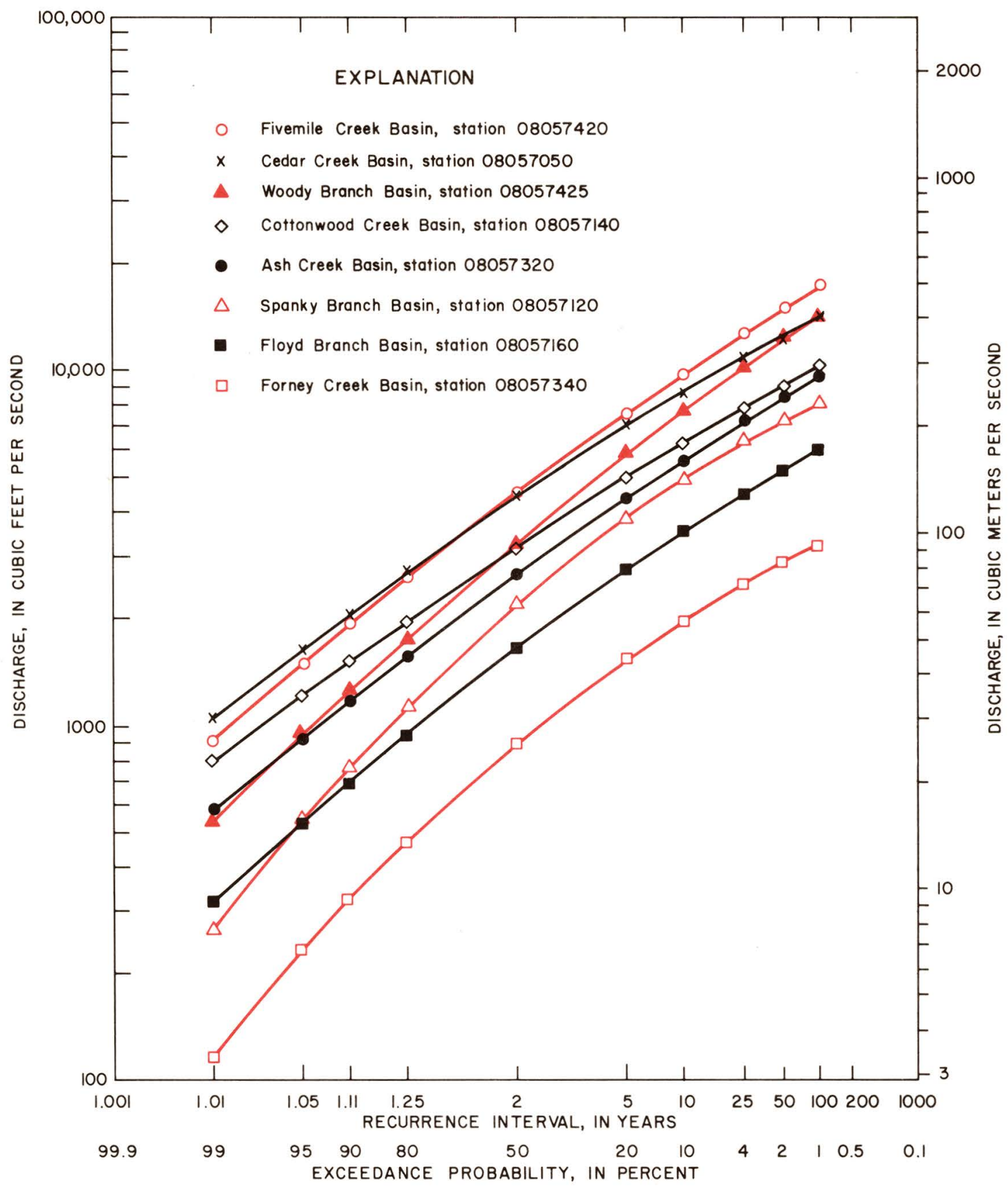

FIGURE 7. - Flood-frequency curves for eight gaging stations based on simulated peak discharges for $1914-70$ 
Table 7.--Storms for which peak discharges were computed from the hydrologic model

\begin{tabular}{|c|c|c|c|}
\hline $\begin{array}{l}\text { Water } \\
\text { year }\end{array}$ & $\begin{array}{l}\text { Storm } \\
\text { date }\end{array}$ & & $\begin{array}{l}\text { Total } \\
\text { rainfall } \\
\text { (in) }\end{array}$ \\
\hline \multirow[t]{4}{*}{1914} & Dec. & 2 & 2.19 \\
\hline & May & 4 & 2.20 \\
\hline & Aug. & 25,26 & 2.06 \\
\hline & Sept. & 22 & 2.04 \\
\hline 1915 & Aug. & $\begin{array}{l}17,18 \\
24\end{array}$ & $\begin{array}{l}6.91 \\
2.87\end{array}$ \\
\hline \multirow[t]{2}{*}{1916} & Jan. & 26 & 2.65 \\
\hline & Aug. & 5 & 1.99 \\
\hline \multirow[t]{3}{*}{1917} & Oct. & 13 & 2.79 \\
\hline & May. & 20 & 1.38 \\
\hline & Aug. & 18 & 1.65 \\
\hline \multirow[t]{3}{*}{1918} & Apr. & 5 & 3.50 \\
\hline & May & 27 & 2.23 \\
\hline & Aug. & 24 & 2.41 \\
\hline \multirow[t]{2}{*}{1919} & oct. & 26 & 2.66 \\
\hline & Sept. & 21 & 2.00 \\
\hline \multirow[t]{2}{*}{1.920} & Oct. & 31 & 3.47 \\
\hline & Már. & 24 & 3.97 \\
\hline \multirow[t]{2}{*}{1921} & Apr. & 21 & 1.66 \\
\hline & May & 1 & 1.41 \\
\hline \multirow[t]{2}{*}{1922} & Apr. & 3 & 4.63 \\
\hline & & 25 & 4.88 \\
\hline \multirow[t]{2}{*}{1923} & June & 2 & 3.43 \\
\hline & & 10 & 3.66 \\
\hline \multirow[t]{2}{*}{1924} & Oct. & 14 & 2.99 \\
\hline & May & 26 & 2.74 \\
\hline 1925 & May & 7 & 2.89 \\
\hline
\end{tabular}

\begin{tabular}{|c|c|c|c|}
\hline $\begin{array}{l}\text { Water } \\
\text { year }\end{array}$ & $\begin{array}{l}\text { Storm } \\
\text { date }\end{array}$ & & $\begin{array}{l}\text { Total } \\
\text { rainfall } \\
\text { (in) }\end{array}$ \\
\hline 1925 & $\begin{array}{l}\text { May } \\
\text { June }\end{array}$ & $\begin{array}{r}10 \\
8\end{array}$ & $\begin{array}{l}1.57 \\
2.56\end{array}$ \\
\hline \multirow[t]{4}{*}{1926} & Apr. & 10 & 2.37 \\
\hline & July & 7 & 1.65 \\
\hline & Aug. & 17,18 & 2.79 \\
\hline & Sept. & 6 & 2.28 \\
\hline \multirow[t]{2}{*}{1927} & Mar. & 7 & 3.06 \\
\hline & July & 22 & 1.66 \\
\hline \multirow[t]{2}{*}{1928} & Oct. & 1 & 3.04 \\
\hline & Apr. & 5 & 2.02 \\
\hline 1929 & May & 13 & 3.45 \\
\hline \multirow[t]{2}{*}{1930} & May & 3 & 1.54 \\
\hline & & 12 & 2.49 \\
\hline 193.1 & Sept. & 11 & 2.74 \\
\hline 1932 & Sept. & $3-5$ & 5.90 \\
\hline 1933 & Apr. & 25 & 3.40 \\
\hline 1934 & Sept. & 14 & 4.40 \\
\hline 1935 & June & 14,15 & 4.70 \\
\hline 1936 & Sept. & 26,27 & 6.72 \\
\hline \multirow[t]{3}{*}{1937} & June & 4 & 1.29 \\
\hline & & 16 & 2.19 \\
\hline & $\begin{array}{l}\text { Aug. } \\
\text { Sept. }\end{array}$ & 23 & $\begin{array}{l}1.39 \\
1.24\end{array}$ \\
\hline \multirow[t]{2}{*}{1938} & Oct. & 17 & 2.70 \\
\hline & Jan. & 21 & 3.00 \\
\hline 1939 & Apr. & 5 & 2.33 \\
\hline 1940 & Oct. & 9 & 1.90 \\
\hline
\end{tabular}

\begin{tabular}{|llll|}
\hline Water & $\begin{array}{l}\text { Storm } \\
\text { date }\end{array}$ & & $\begin{array}{c}\text { Total } \\
\text { rainfal1 } \\
\text { (in) }\end{array}$ \\
\hline 1941 & June & 1,2 & 2.76 \\
1942 & Apr. & $18-20$ & 3.38 \\
& May & 6 & 2.01 \\
& Sept. & 6 & 2.27 \\
1943 & Oct. & 15,16 & 4.50 \\
1944 & Mar. & 18,19 & 2.89 \\
& Apr.30,May 1 & 3.44 \\
& July & 12 & 2.21 \\
1945 & July & 5 & 5.34 \\
1946 & May & 28,29 & 6.24 \\
1947 & Nov. & 2 & 4.83 \\
& Aug. & 26,27 & 9.45 \\
1948 & June & 28 & 2.93 \\
1949 & Jan. & 24 & 4.88 \\
& May & 16,17 & 5.46 \\
1950 & Oct. & 24 & 2.99 \\
& May & 1 & 1.82 \\
1951 & June & 2 & 3.22 \\
& Sept. & 12 & 2.38 \\
1952 & May & 17 & 2.21 \\
1953 & Apr. & 23 & 1.53 \\
1954 & Oct. & 28 & 2.42 \\
& Apr. & 11,12 & 2.31 \\
1955 & May & $10-12$ & 4.43 \\
& & 19 & 1.31 \\
\hline
\end{tabular}

\begin{tabular}{|llll|}
\hline $\begin{array}{llll}\text { Water } \\
\text { year }\end{array}$ & $\begin{array}{l}\text { Storm } \\
\text { date }\end{array}$ & \multicolumn{2}{c|}{$\begin{array}{c}\text { Total } \\
\text { rainfal1 } \\
\text { (in) }\end{array}$} \\
\hline 1955 & June & 4 & 1.51 \\
1956 & Apr. & 29 & 2.24 \\
& May & 1 & 2.20 \\
1957 & Mar. & 31 & 2.89 \\
& Apr. & 26 & 5.09 \\
& May & 23 & 3.38 \\
1958 & Mar. & 29 & 3.05 \\
& Apr. & 26 & 3.39 \\
1959 & July & 19 & 1.53 \\
& Sept. & 28 & 1.96 \\
1960 & Oct. & 1 & 6.30 \\
& July & 13 & 4.13 \\
1961 & Sept. & 12 & 4.02 \\
1962 & July & $25-27$ & 8.47 \\
1963 & Oct. & 8 & 4.92 \\
1964 & Sept. & $20-22$ & 7.51 \\
1965 & May & 10 & 2.63 \\
& Sept. & 21 & 3.45 \\
1966 & Apr. & 28 & 3.61 \\
1967 & Apr. & 21 & 1.76 \\
1968 & May & 12,13 & 1.73 \\
& Aug. & 13,14 & 2.48 \\
1969 & Oct. & 9 & 2.44 \\
& May & 6,7 & 5.43 \\
1970 & Oct. & 12 & 4.39 \\
& May & 30 & 1.96 \\
- & - - - & & - \\
\hline
\end{tabular}


Table 8.--summary of simulated peak-discharge data

\begin{tabular}{|c|c|c|c|c|c|c|c|c|c|c|c|c|c|c|}
\hline \multirow{2}{*}{$\begin{array}{l}\text { Water } \\
\text { year }\end{array}$} & \multicolumn{2}{|c|}{$\begin{array}{l}\text { Joes Creek } \\
\text { (No. } 8-556)\end{array}$} & \multicolumn{2}{|c|}{$\begin{array}{l}\text { Bachman Branch } \\
\text { (No. 8-557) }\end{array}$} & \multicolumn{2}{|c|}{$\begin{array}{l}\text { Turtle Creek } \\
\text { (No. 8-565) }\end{array}$} & \multicolumn{2}{|c|}{$\begin{array}{l}\text { Coombs Creek } \\
\text { (No. 8-570.2) }\end{array}$} & \multicolumn{2}{|c|}{$\begin{array}{l}\text { Cedar Creek } \\
\text { (No. } 8-570.5 \text { ) }\end{array}$} & \multicolumn{2}{|c|}{$\begin{array}{c}\text { White Rock Creek } \\
\text { (No. 8-571) }\end{array}$} & \multicolumn{2}{|c|}{$\begin{array}{l}\text { Spanky Branch } \\
\text { (No. 8-57l.2) }\end{array}$} \\
\hline & $\begin{array}{c}\text { Discharge } \\
\text { (cfs) }\end{array}$ & Rank & $\begin{array}{c}\text { Discharge } \\
\text { (cfs) }\end{array}$ & Rank & $\begin{array}{c}\text { Discharge } \\
\text { (cfs) }\end{array}$ & Rank & $\begin{array}{c}\text { Discharge } \\
\text { (cfs) }\end{array}$ & Rank & $\begin{array}{c}\text { Discharge } \\
\text { (cfs) }\end{array}$ & Rank & $\begin{array}{c}\text { Discharge } \\
\text { (cfs) }\end{array}$ & Rank & $\begin{array}{c}\text { Discharge } \\
\text { (cfs) }\end{array}$ & $\operatorname{Rank}$ \\
\hline 1914 & 3,080 & 21 & 4,770 & 17 & 3,500 & 27 & 2,140 & 31 & 4,590 & 30 & 6,260 & 30 & 2,250 & $\cdot 30$ \\
\hline 15 & 2,210 & 33 & 1,930 & 48 & 2,350 & 44 & 754 & 55 & 2,530 & 47 & 5,010 & 38 & 1,350 & 43 \\
\hline 16 & 2,400 & 30 & 3,320 & 33 & 4,580 & 17 & 3,130 & 21 & 5,480 & 18 & 7,290 & 27 & 2,850 & 21 \\
\hline 17 & 1,720 & 41 & 3,230 & 36 & 2,900 & 34 & 2,000 & 35 & 3,910 & 35 & 4,410 & 39 & 1,660 & 38 \\
\hline 18 & 1,400 & 44 & 2,600 & 42 & 2,490 & 42 & 1,690 & 40 & 3,280 & 42 & 3,440 & 46 & 1,290 & 45 \\
\hline 19 & 3,380 & 16 & 4,120 & 24 & 4,340 & 19 & 2,280 & 27 & 5,330 & 21 & 8,050 & 24 & 2,720 & 24 \\
\hline 1920 & 4,160 & 11 & 7,080 & 10 & 5,220 & 13 & 3,420 & 16 & 6,860 & 13 & 11,700 & 12 & 3,630 & 13 \\
\hline 21 & 966 & 52 & 1,460 & 51 & 1,640 & 51 & 1,100 & 51 & 2,090 & 51 & 1,650 & 54 & 613 & 52 \\
\hline 22 & 5,210 & 5 & 7,600 & 9 & 5,160 & 15 & 3,240 & 19 & 7,760 & 11 & 13,100 & 11 & 3,690 & 11 \\
\hline 23 & 3,440 & 13 & 4,060 & 25 & 5,830 & 12 & 3,650 & 12 & 6,670 & 14 & 9,250 & 17 & 3,410 & 15 \\
\hline 24 & 1,740 & 40 & 2,930 & - 39 & 2,760 & 37 & 1,600 & 42 & 3,510 & 38 & 4,300 & 41 & 1,430 & 41 \\
\hline 25 & 2,440 & 28 & 4,600 & 19 & 4,300 & 20 & 2,740 & 22 & 5,480 & 19 & 6,570 & 29 & 2,510 & 26 \\
\hline 26 & 1,320 & 47 & 2,200 & 46 & 2,380 & 43 & 1,570 & 44 & 3,000 & 45 & 3,700 & 42 & 1,460 & 40 \\
\hline .27 & 2,460 & 27 & 3,300 & 34 & 3,200 & 29 & 2,030 & 33 & 4,650 & 28 & 7,560 & 26 & 2,450 & 27 \\
\hline 28 & 1,330 & 46 & 2,350 & 44 & 2,540 & 41 & 1,580 & 43 & 3,160 & 43 & 3,180 & 49 & 1,000 & 49 \\
\hline 29 & 5,120 & 7 & 8,660 & 7 & 7,150 & 7 & 6,910 & 2 & 9,690 & 6 & 14,600 & 7 & 5,440 & 6 \\
\hline 1930 & 3,150 & -18 & 3,480 & 30 & 4,830 & 16 & 3,530 & 13 & 5,290 & 22 & 9,180 & 18 & 3,220 & 16 \\
\hline 31 & 2,210 & 32 & 3,870 & 27 & 3,590 & 26 & 2,260 & 28 & 4,780 & 27 & 5,990 & 32 & 2,000 & 31 \\
\hline 32 & 3,390 & 15 & 5,730 & 15 & 4,070 & 22 & 3,320 & 17 & 6,160 & 15 & 11,400 & 13 & 3,580 & 14 \\
\hline 33 & 2,560 & 26 & 4,480 & 20 & 3,820 & 24 & 2,510 & 25 & 5,230 & 23 & 7,080 & 28 & 2,430 & 29 \\
\hline 34 & 2,020 & $: 36$ & 3,130 & 37 & 2,310 & 45 & 1,520 & 45 & 3,290 & 41 & 5,940 & 33 & 1,800 & 36 \\
\hline 35 & 2,720 & 24 & 4,310 & 23 & 3,290 & 28 & 1,990 & 36 & 4,930 & 26 & 8,330 & 22 & 2,430 & 28 \\
\hline 36 & $-1,900$ & 38 & 2,380 & 43 & 2,200 & 46 & 1,820 & 38 & 3,120 & 44 & 5,200 & 36 & 1,750 & 37 \\
\hline 37 & 709 & 55 & 1,260 & 54 & 1,520 & 52 & 1,020 & 53 & 1,830 & 53 & 1,090 & 56 & 417 & 55 \\
\hline 38 & 2,560 & 25 & 5,590 & 16 & 5,170 & 14 & 3,160 & 20 & 5,820 & 16 & 8,600 & 21 & 3,040 & 19 \\
\hline 39 & 1,140 & 50 & 1,360 & 52 & 1,490 & 53 & 991 & 54 & 1,920 & 52 & 2,840 & 50 & 818 & 50 \\
\hline 1940 & 707 & 56 & 1,060 & 56 & 1,260 & 56 & 723 & 56. & 1,480 & 56 & 1,010 & 57 & 317 & 57 \\
\hline 41 & 3,010 & -23 & 4,750 & 18 & 2,700 & 38 & 1,750 & 39 & 4,140 & 33 & 5,290 & 34 & 1,930 & 34 \\
\hline 42 & 3,200 & 17 & 4,450 & 21 & 4,430 & 18 & 3,490 & 15 & 5,810 & 17 & 9,140 & 20 & 3,160 & 18 \\
\hline 43 & 1,610 & . 42 & 2,880 & 40 & 2,580 & 40 & 1,650 & 41 & 3,310 & 40 & 3,680 & 43 & 1,260 & 46 \\
\hline
\end{tabular}


Table 8.--Summary of simulated peak-discharge data--Continued

\begin{tabular}{|c|c|c|c|c|c|c|c|c|c|c|c|c|c|c|}
\hline \multirow{2}{*}{$\begin{array}{l}\text { Water } \\
\text { year }\end{array}$} & \multicolumn{2}{|c|}{$\begin{array}{l}\text { Joes Creek } \\
\text { (No. } 8-556 \text { ) }\end{array}$} & \multicolumn{2}{|c|}{$\begin{array}{l}\text { Bachman Branch } \\
\text { (No. 8-557) }\end{array}$} & \multicolumn{2}{|c|}{$\begin{array}{l}\text { Turtie Creek } \\
\text { (No. 8-565) }\end{array}$} & \multicolumn{2}{|c|}{$\begin{array}{l}\text { Coombs Creek } \\
\text { (No. 8-570.2) }\end{array}$} & \multicolumn{2}{|c|}{$\begin{array}{c}\text { Cedar Creek } \\
\text { (No. } 8-570.5 \text { ) } \\
\end{array}$} & \multicolumn{2}{|c|}{$\begin{array}{l}\text { White Rock Creek } \\
\text { (No. 8-571) }\end{array}$} & \multicolumn{2}{|c|}{$\begin{array}{l}\text { Spanky Branch } \\
\text { (No. 8-571.2) }\end{array}$} \\
\hline & $\begin{array}{c}\text { Discharge } \\
\text { (cfs) }\end{array}$ & Rank & $\begin{array}{c}\text { Discharge } \\
\text { (cfs) }\end{array}$ & Rank & $\begin{array}{c}\text { Discharge } \\
\text { (cfs) }\end{array}$ & Rank & $\begin{array}{c}\text { Discharge } \\
\text { (cfs) }\end{array}$ & Rank & $\begin{array}{c}\text { Discharge } \\
\text { (cfs) }\end{array}$ & Rank & $\begin{array}{c}\text { Discharge } \\
\text { (cfs) }\end{array}$ & Rank & $\begin{array}{c}\text { Discharge } \\
\text { (cfs) }\end{array}$ & $\overline{\operatorname{Rank}}$ \\
\hline 1944 & 1,880 & 39 & 3,300 & 35 & 2,770 & 36 & 2,280 & 26 & 3,580 & 37 & 8,240 & 23 & 2,620 & 25 \\
\hline 45 & 5,820 & 2 & 10,640 & 2 & 8,130 & 2 & 7,700 & 1 & 11,400 & 1 & 19,500 & 2 & 6,480 & 2 \\
\hline 46 & 5,710 & 3 & 9,570 & 4 & 8,110 & 3 & 5,950 & 3 & 11,100 & 2 & 19,200 & 3 & 6,390 & 3 \\
\hline 47 & 7,200 & 1 & 10,900 & 1 & 7,420 & 6 & 5,070 & 7 & 10,800 & 3 & 25,500 & 1 & 6,930 & 1 \\
\hline 48 & 1,460 & 43 & 1,340 & 53 & 1,360 & 55 & 1,120 & 49 & 1,780 & 54 & 3,530 & 45 & 1,060 & 48 \\
\hline 49 & 4,010 & 12 & 6,380 & 12 & 6,990 & 8 & 4,620 & 8 & 7,820 & 9 & 13,700 & 9 & 4,530 & 9 \\
\hline 1950 & 3,040 & $-\quad 22$ & 3,390 & 31 & 4,290 & 21 & 2,610 & 23 & 4,990 & 25 & 9,180 & 19 & 2,830 & 22 \\
\hline $5 I$ & 2,410 & 29 & 3,320 & 32 & 3,170 & 30 & 2,200 & 30 & 4,200 & 32 & 6,190 & 31 & 1,970 & 32 \\
\hline 52 & 1,320 & 48 & 2,240 & 45 & 2,030 & 47 & 1,340 & 47 & 2,730 & 46 & 3,240 & 48 & 1,200 & 47 \\
\hline 53 & 1,280 & 49 & 2,100 & 47 & 1,720 & 50 & 1,460 & 46 & 2,360 & 48 & 3,570 & 44 & 1,360 & 42 \\
\hline 54 & 883 & 54 & 1,090 & 55 & 1,370 & 54 & 1,040 & 52 & 1,640 & 55 & 1,990 & 51 & 560 & 54 \\
\hline 55 & 895 & 53 & 1,590 & 49 & 1,750 & 48 & 1,190 & 48 & 2,200 & 49 & 1,710 & 53 & 653 & 51 \\
\hline 56 & 2,240 & 31 & 4,060 & 26 & 3,020 & 33 & 3,280 & 18 & 4,630 & 29 & 8,040 & 25 & 2,720 & 23 \\
\hline 57 & 4,540 & 9 & 8,460 & 8 & 6,790 & 10 & 4,060 & 11 & 7,780 & 10 & 13,400 & 10 & 4,230 & 10 \\
\hline 58 & 3,120 & 19 & 6,710 & 11 & 5,940 & II & 4,380 & 10 & 7,120 & 12 & 10,100 & 15 & 3,790 & 12 \\
\hline 59 & 1,400 & 45 & 2,660 & 41 & 2,600 & 39 & 1,850 & 37 & 3,410 & 39 & 3,430 & 47 & 1,300 & 44 \\
\hline 1960 & 5,190 & 6 & 9,480 & 5 & 8,010 & 4 & 5,800 & 4 & 10,700 & 4 & 17,600 & 4 & 5,620 & 4 \\
\hline 61 & 673 & 57 & 832 & 57 & 822 & 57 & 459 & 57 & 1,020 & 57 & 1,520 & 55 & 397 & 56 \\
\hline 62 & 4,650 & 8 & 8,840 & 6 & 6,900 & 9 & 5,630 & 5 & 9,610 & 7 & 15,500 & 6 & 5,130 & 7 \\
\hline 63 & 3,410 & 14 & 6,150 & 14 & 3,650 & 25 & 2,560 & 24 & 5,380 & 20 & 11,000 & 14 & 3,180 & 17 \\
\hline 64 & 3,080 & 20 & 4,420 & 22 & 3,820 & 23 & 3,500 & 14 & 5,050 & 24 & 9,480 & 16 & 2,980 & 20 \\
\hline 65 & 2,060 & 35 & 3,720 & 28 & 3,030 & 32 & 2,250 & 29 & 4,130 & 34 & 5,220 & 35 & 1,940 & 33 \\
\hline 66 & 5,520 & 4 & 10,100 & 3 & 9,220 & $I$ & 5,550 & 6 & 10,300 & 5 & 15,500 & 5 & 5,530 & 5 \\
\hline 67 & 1,020 & 51 & 1,560 & 50 & 1,750 & 49 & 1,100 & 50 & 2,110 & 50 & 1,840 & 52 & 604 & 53 \\
\hline 68 & 2,140 & 34 & 3,120 & 38 & 2,870 & 35 & 2,030 & 34 & 3,870 & 36 & 4,340 & 40 & 1,640 & 39 \\
\hline 69 & 4,500 & 10 & 6,310 & 13 & 7,710 & 5 & 4,490 & 9 & 8,430 & 8 & 14,600 & 8 & 4,630 & 8 \\
\hline 1970 & 1,910 & 37 & 3,610 & 29 & 3,060 & 31 & 2,110 & 32 & 4,230 & 31 & 5,020 & 37 & 1,900 & 35 \\
\hline
\end{tabular}


Table 8.--Summary of simulated peak-discharge data--Continued

\begin{tabular}{|c|c|c|c|c|c|c|c|c|c|c|c|c|c|c|}
\hline \multirow{2}{*}{$\begin{array}{l}\text { Water } \\
\text { year }\end{array}$} & \multirow{2}{*}{$\begin{array}{l}\text { Cottonwood } \\
\text { (No. 8-57 } \\
\text { Discharge } \\
\text { (cfs) }\end{array}$} & \multirow{2}{*}{$\begin{array}{l}\text { Creek } \\
\text { (.4) } \\
\text { Rank }\end{array}$} & \multicolumn{2}{|c|}{$\begin{array}{l}\text { Floyd Branch } \\
\text { (No. 8-571.6) }\end{array}$} & \multicolumn{2}{|c|}{$\begin{array}{l}\text { White Rock Creek } \\
\text { (No. 8-572) }\end{array}$} & \multicolumn{2}{|c|}{$\begin{array}{c}\text { Ash Creek } \\
\text { (No. } 8-573.2 \text { ) }\end{array}$} & \multicolumn{2}{|c|}{$\begin{array}{l}\text { Forney Creek } \\
\text { (No. 8-573.4) }\end{array}$} & \multicolumn{2}{|c|}{$\begin{array}{l}\text { Fivemile Creek } \\
\text { (No. } 8-574.2 \text { ) }\end{array}$} & \multicolumn{2}{|c|}{$\begin{array}{l}\text { Woody Branch } \\
\text { (No. } 8-574.25 \text { ) }\end{array}$} \\
\hline & & & $\begin{array}{c}\text { Discharge } \\
\text { (cfs) }\end{array}$ & Rank & $\begin{array}{c}\text { Discharge } \\
(\mathrm{cfs})\end{array}$ & Rank & $\begin{array}{c}\text { Discharge } \\
\text { (cfs) }\end{array}$ & Rank & $\begin{array}{c}\text { Discharge } \\
\text { (cfs) }\end{array}$ & Rank & $\begin{array}{c}\text { Discharge } \\
\text { (cfs) }\end{array}$ & Rank & $\begin{array}{c}\text { Discharge } \\
\text { (cfs) }\end{array}$ & $\overline{\text { Rank }}$ \\
\hline 1914 & 3,250 & 29 & 1,950 & 22 & 13,900 & 18 & 3,180 & 22 & 1,240 & 17 & 5,480 & 20 & 4,190 & 19 \\
\hline 15 & 2,160 & 45 & 1,110 & 42 & 12,600 & 22 & 1,870 & 42 & 368 & 49 & 3,400 & 40 & 2,760 & 35 \\
\hline 16 & 3,710 & 22 & 1,820 & 26 & 9,060 & 37 & 2,860 & 28 & 954 & 26 & 4,080 & 35 & 2,840 & 33 \\
\hline 17 & 2,690 & 35 & 1,300 & 35 & 9,040 & 38 & 2,180 & 36 & 760 & 32 & 3,690 & 37 & 2,370 & 40 \\
\hline 18 & 2,300 & 42 & 1,060 & 44 & 7,080 & 46 & 1,820 & 43 & 604 & 43 & 3,000 & 46 & 1,960 & 47 \\
\hline 19 & 3,800 & 19 & 1,990 & 21 & 11,100 & 32 & 3,280 & 20 & 771 & 31 & 4,160 & 31 & 2,960 & 32 \\
\hline 1920 & 5,140 & 12 & 2,810 & 12 & 23,300 & 11 & 4,710 & 11 & 1,590 & 13 & 8,320 & 11 & 6,830 & 11 \\
\hline 21 & 1,470 & 51 & 711 & 49 & 4,980 & 50 & 1,160 & 50 & 490 & 48 & 2,190 & 49 & 1,450 & 49 \\
\hline 22 & 5,760 & 9 & 3,470 & 10 & 30,400 & 4 & 5,720 & 9 & 1,700 & 12 & 10,100 & 8 & 7,960 & 8 \\
\hline 23 & 4,530 & 15 & 2,090 & 19 & 11,200 & 31 & 3,330 & 19 & 1,000 & 24 & 4,840 & 24 & 3,440 & 24 \\
\hline 24 & 2,480 & 39 & 1,240 & 39 & 8,480 & 40 & 2,150 & 37 & 595 & 45 & 3,380 & 41 & 2,240 & 42 \\
\hline 25 & 3,790 & 20 & 1,900 & 24 & 12,200 & 27 & 3,100 & 24 & 1,110 & 20 & 5,410 & 21 & 3,660 & 23 \\
\hline 26 & 2,140 & 46 & 996 & 46 & 7,470 & 43 & 1,690 & 46 & 807 & 30 & 3,170 & 43 & 2,340 & 41 \\
\hline 27 & 3,380 & 27 & 1,920 & 23 & 12,400 & 25 & 2,960 & 25 & 862 & 29 & 4,510 & 28 & 3,300 & 27 \\
\hline 28 & 2,210 & 44 & 1,000 & 45 & 7,290 & 44 & 1,750 & 45 & 533 & 46 & 3,190 & 42 & 2,050 & 45 \\
\hline 29 & 6,570 & 7 & 3,480 & 9 & 22,400 & 12 & 5,530 & 10 & 2,340 & 3 & 10,800 & 7 & 8,170 & 7 \\
\hline 1930 & 3,590 & 25 & 1,800 & 27 & 10,300 & 34 & 2,890 & 26 & 731 & 33 & 4,300 & 29 & 3,080 & 31 \\
\hline 31 & 3,370 & 28 & 1,670 & 30 & 11,300 & 30 & 2,830 & 29 & 715 & 37 & 4,690 & 26 & 3,190 & 29 \\
\hline 32 & 4,570 & 14 & 2,450 & 14 & 19,400 & 15 & 3,950 & 14 & 1,220 & 19 & 7,160 & 15 & 5,570 & 15 \\
\hline 33 & 3,670 & 24 & 1,860 & 25 & 13,400 & 20 & 3,150 & 23 & 1,020 & 23 & 5,810 & 18 & 4,050 & 20 \\
\hline 34 & 2,540 & 37 & 1,270 & 38 & 11,700 & 28 & 2,100 & 39 & 695 & 39 & 3,610 & 39 & 2,570 & 38 \\
\hline 35 & 3,730 & 21 & 2,170 & 18 & 17,300 & 16 & 3,530 & 18 & 998 & 25 & 6,290 & 17 & 4,810 & 17 \\
\hline 36 & 2,280 & 43 & 1,130 & 41 & 7,500 & 42 & 1,940 & 41 & 609 & 42 & 3,010 & 45 & 2,180 & 43 \\
\hline 37 & 1,280 & 54 & 534 & 54 & 3,360 & 55 & 889 & 54 & 252 & 52 & 1,460 & 54 & 938 & 54 \\
\hline 38 & 3,980 & 18 & 2,330 & 16 & 16,400 & 17 & 3,720 & 16 & 1,440 & 14 & 6,470 & 16 & 5,070 & 16 \\
\hline 39 & 1,360 & 53 & 709 & 50 & 6,450 & 47 & 1,190 & 49 & 355 & 50 & 2,020 & 50 & 1,430 & 50 \\
\hline 1940 & 1,110 & 56 & 456 & 56 & 3,010 & 57 & 823 & 55 & 155 & 56 & 1,260 & 56 & 721 & 56 \\
\hline 41 & 2,910 & 33 & 1,660 & 31 & 12,500 & 24 & 2,600 & 31 & 1,100 & 21 & 5,190 & 23 & 3,920 & 22 \\
\hline 42 & 4,170 & 16 & 2,310 & 17 & 13,800 & 19 & 3,630 & 17 & 1,290 & 16 & 5,710 & 19 & 4,620 & 18 \\
\hline 43 & 2,360 & 40 & 1,230 & 40 & 8,830 & 39 & 2,140 & 38 & 653 & 40 & 3,700 & 36 & 2,480 & 39 \\
\hline
\end{tabular}


Table 8.--Summary of simulated peak-discharge data--Concluded

\begin{tabular}{|c|c|c|c|c|c|c|c|c|c|c|c|c|c|c|}
\hline \multirow{2}{*}{$\begin{array}{l}\text { watex } \\
\text { year }\end{array}$} & \multicolumn{2}{|c|}{$\begin{array}{l}\text { Cottonwood Creek } \\
\text { (No. 8-571.4) }\end{array}$} & \multicolumn{2}{|c|}{$\begin{array}{l}\text { Floyd Branch } \\
\text { (No. 8-571.6) }\end{array}$} & \multicolumn{2}{|c|}{$\begin{array}{l}\text { White Rock Creek } \\
\text { (No. 8-572) }\end{array}$} & \multicolumn{2}{|c|}{$\begin{array}{c}\text { Ash Creek } \\
\text { (No. } 8-573.2 \text { ) }\end{array}$} & \multicolumn{2}{|c|}{$\begin{array}{l}\text { Forney Creek } \\
(\text { No. } 8-573.4)\end{array}$} & \multicolumn{2}{|c|}{$\begin{array}{l}\text { Fivemile Creek } \\
\text { (No. 8-574.2) }\end{array}$} & \multicolumn{2}{|c|}{$\begin{array}{c}\text { Woody Branch } \\
\text { (No. 8-574.25) }\end{array}$} \\
\hline & $\begin{array}{c}\text { Discharge } \\
\text { (cfs) }\end{array}$ & Rank & $\begin{array}{c}\text { Discharge } \\
\text { (cfs) }\end{array}$ & Rank & $\begin{array}{c}\text { Discharge } \\
\text { (cfs) }\end{array}$ & Rank & $\begin{array}{c}\text { Discharge } \\
\text { (cfs) }\end{array}$ & Rank & $\begin{array}{c}\text { Discharge } \\
\text { (cfs) }\end{array}$ & Rank & $\begin{array}{c}\text { Discharge } \\
\text { (cfs) }\end{array}$ & Rank & $\begin{array}{c}\text { Discharge } \\
\text { (cfs) }\end{array}$ & Rank \\
\hline 1944 & 2,490 & 38 & 1,280 & 37 & 12,600 & 23 & 2,360 & 35 & 727 & 34 & 4,130 & 33 & 3,180 & 30 \\
\hline 1945 & 8,060 & 2 & 4,500 & 2 & 30,200 & 5 & 7,260 & 2 & 2,310 & 4 & 12,800 & 3 & 9,830 & 3 \\
\hline 1946 & 7,820 & 3 & 4,280 & 4 & 33,600 & 2 & 6,860 & 4 & 2,480 & 2 & 13,400 & 2 & 10,300 & 2 \\
\hline 1947 & 8,840 & 1 & 4,610 & 1 & 50,200 & 1 & 7,850 & 1 & 2,180 & 6 & 13,900 & 1 & 11,200 & 1 \\
\hline 1948 & 1,360 & 52 & 617 & 53 & 4,760 & 51 & 1,110 & 53 & 226 & 54 & 1,680 & 53 & 1,120 & 52 \\
\hline 1949 & 5,720 & 10 & 2,820 & 11 & 22,100 & 13 & 4,480 & 12 & 1,710 & 11 & 7,580 & 13 & 5,850 & 14 \\
\hline 1950 & 3,690 & 23 & 2,070 & 20 & 12,300 & 26 & 3,230 & 21 & 718 & 36 & 4,270 & 30 & 3,210 & 28 \\
\hline 51 & 2,970 & 31 & 1,520 & 32 & 9,860 & 35 & 2,500 & 32 & 636 & 41 & 4,100 & 34 & 2,800 & 34 \\
\hline 52 & 2,000 & 47 & 949 & 47 & 6,320 & 49 & 1,580 & 47 & 529 & 47 & 2,600 & 48 & 1,700 & 48 \\
\hline 53 & 1,620 & 48 & 886 & 48 & 6,340 & 48 & 1,380 & 48 & 700 & 38 & 2,730 & 47 & 2,080 & 44 \\
\hline 54 & 1,140 & 55 & 466 & 55 & 3,480 & 54 & 820 & 56 & 214 & 55 & 1,280 & 55 & 828 & 55 \\
\hline 55 & 1,530 & 49 & 665 & 51 & 4,260 & 52 & 1,130 & 52 & 352 & 51 & 1,820 & 51 & 1,200 & 51 \\
\hline 56 & 3,240 & 30 & 1,690 & 29 & 11,300 & 29 & 2,760 & 30 & 934 & 27 & 4,660 & 27 & 3,440 & 25 \\
\hline 57 & 5,700 & 11 & 3,490 & 8 & 28,700 & 6 & 5,830 & 8 & 1,950 & 9 & 9,320 & 10 & 7,510 & 10 \\
\hline 58 & 4,840 & 13 & 2,650 & 13 & 20,400 & 14 & 4,170 & 13 & 1,990 & 8 & 7,950 & 12 & 6,260 & 12 \\
\hline 59 & 2,350 & 41 & 1,100 & 43 & 7,220 & 45 & 1,800 & 44 & 603 & 44 & 3,080 & 44 & 1,970 & 46 \\
\hline 1960 & 7,260 & 4 & 3,920 & 5 & 25,700 & 7 & 6,240 & 5 & 2,300 & 5 & 11,300 & 5 & 8,390 & 6 \\
\hline 61 & 832 & 57 & 360 & 57 & 3,360 & 56 & 659 & 57 & 124 & 57 & 999 & 57 & 637 & 57 \\
\hline 62 & 6,850 & 6 & 3,700 & 6 & 25,700 & 8 & 6,120 & 6 & 2,030 & 7 & 10,900 & 6 & 8,620 & 5 \\
\hline 63 & 4,140 & 17 & 2,360 & 15 & 25,100 & 9 & 3,820 & 15 & 1,380 & 15 & 7,530 & 14 & 5,950 & 13 \\
\hline 64 & 3,420 & 26 & 1,790 & 28 & 13,100 & 21 & 2,860 & 27 & 1,230 & 18 & 5,260 & 22 & 3,970 & 21 \\
\hline 65 & 2,880 & 34 & 1,460 & 33 & 10,500 & 33 & 2,480 & 33 & 1,030 & 22 & 4,810 & 25 & 3,320 & 26 \\
\hline 66 & 7,210 & 5 & 4,410 & 3 & 31,700 & 3 & 6,980 & 3 & 2,680 & 1 & 12,000 & 4 & 9,630 & 4 \\
\hline 67 & 1,510 & 50 & 645 & 52 & 4,180 & 53 & 1,160 & 51 & 248 & 53 & 1,770 & 52 & 1,040 & 53 \\
\hline 68 & 2,680 & 36 & 1,280 & 36 & 8,370 & 41 & 2,100 & 40 & 720 & 35 & 3,680 & 38 & 2,750 & 36 \\
\hline 69 & 6,350 & 8 & 3,620 & 7 & 24,700 & 10 & 6,120 & 7 & 1,900 & 10 & 9,690 & 9 & 7,910 & 9 \\
\hline 1970 & 2,920 & 32 & 1,440 & 34 & 9,570 & 36 & 2,400 & 34 & 887 & 28 & 4,150 & 32 & 2,730 & 37 \\
\hline
\end{tabular}


Table 9.--Station flood-frequency characteristics computed from simulated peak discharges

\begin{tabular}{|c|c|c|c|c|c|c|c|c|c|c|c|}
\hline \multirow{2}{*}{$\begin{array}{l}\text { Gaging } \\
\text { station } \\
\text { No. } \\
\text { (fig. 3) }\end{array}$} & \multirow[t]{2}{*}{ Basin name } & \multicolumn{7}{|c|}{$\begin{array}{c}\text { Peak discharge, } Q_{\mathrm{T}} \text { (cfs) at indicated } \\
\text { recurrence interval, } \mathrm{T} \text { (years) } \\
\text { (Number in parenthesis is exceedance probability in percent) }\end{array}$} & \multicolumn{3}{|c|}{$\begin{array}{c}\text { Log-Pearsor Type III } \\
\text { statistics }\end{array}$} \\
\hline & & $\begin{array}{l}Q_{1.25} \\
(80)\end{array}$ & $\mathrm{Q}_{2}$ & ${ }_{5}(20)$ & $\begin{array}{l}Q_{10} \\
(10)\end{array}$ & $\begin{array}{l}25 \\
(4)\end{array}$ & $\begin{array}{l}Q_{50} \\
(2)\end{array}$ & $\begin{array}{l}{ }^{2} 100 \\
(1)\end{array}$ & $\begin{array}{l}\text { Mean, } \\
\text { logs }\end{array}$ & $\begin{array}{c}\begin{array}{c}\text { Standard } \\
\text { deviation, } \\
\text { logs }\end{array} \\
\end{array}$ & $\begin{array}{l}\text { Skew- } \\
\text { ness } \\
\text { logs }\end{array}$ \\
\hline $8-556$ & Joes Creek & 1,420 & 2,370 & 3,820 & 4,840 & 6,170 & 7,180 & 8,200 & 3.364 & 0.256 & -0.244 \\
\hline $8-557$ & Bachman Branch & 2,130 & 3,710 & 6,230 & 8,070 & 10,500 & 12,400 & 14,400 & 3.558 & .278 & -.235 \\
\hline $8-565$ & Turtle Creek & 2,110 & 3,410 & 5,400 & 6,820 & 8,680 & 10,100 & 11,600 & 3.526 & .243 & -.159 \\
\hline $8-570.2$ & Coombs Creek & 1,380 & 2,330 & 3,830 & 4,920 & 6,370 & 7,490 & 8,650 & 3.360 & .264 & -.185 \\
\hline $8-570.5$ & Cedar Creek & 2,740 & 4,480 & 7,040 & 8,790 & 11,000 & 12,700 & 14,300 & 3.639 & .245 & -.292 \\
\hline $8-571$ & $\begin{array}{c}\text { White Rock Creek above } \\
\text { Keller Springs Road }\end{array}$ & 3,340 & 6,510 & 11,700 & 15,400 & 20,100 & 23,600 & 27,100 & 3.788 & .326 & -.468 \\
\hline $8-571.2$ & Spanky Branch & 1,140 & 2,220 & 3,900 & 5,030 & 6,420 & 7,410 & 8,340 & 3.314 & .323 & -.602 \\
\hline $8-571.4$ & Cottonwood Creek & 1,960 & 3,180 & 5,010 & 6,290 & 7,970 & 9,240 & 10,500 & 3.494 & .242 & -.194 \\
\hline $8-571.6$ & Floyd Branch & 945 & 1,640 & 2,730 & 3,510 & 4,520 & 5,280 & 6,050 & 3.202 & .275 & -.294 \\
\hline $8-572$ & $\begin{array}{c}\text { White Rock Creek above } \\
\text { Greenville Avenue }\end{array}$ & 6,600 & 11,600 & 20,000 & 26,600 & 35,900 & 43,600 & 51,800 & 4.059 & .286 & -.044 \\
\hline $8-573.2$ & Ash Creek & 1,590 & 2,700 & 4,430 & 5,670 & 7,300 & 8,550 & 9,820 & 3.422 & .265 & -.232 \\
\hline $8-573.4$ & Forney Creek & 472 & 900 & 1,560 & 2,000 & 2,540 & 2,920 & 3,290 & 2.924 & .313 & -.582 \\
\hline $8-574.2$ & Fivemile Creek & 2,640 & 4,580 & 7,700 & 9,960 & 13,000 & 15,300 & 17,700 & 3.651 & .277 & -.230 \\
\hline $8-574.25$ & Woody Branch & 1,790 & 3,320 & 5,880 & 7,810 & 10,400 & 12,500 & 14,600 & 3.508 & .308 & -.259 \\
\hline
\end{tabular}


The flood-frequency curves generally fit most of the observed data; however, because of the unusually high floods that occurred during 1962-70, the observed data plotted erratically in the upper parts of the curves. The probability of exceedance of these higher flows is unknown even when adjusted historically (Dalrymple, 1960).

\section{REGIONALIZATION OF FLOOD-PEAK CHARACTERISTICS}

Multiple-regression techniques are useful in regionalizing streamflow characteristics because discharge for a given recurrence interval can be related to the physical and (or) climatic characteristics of the basins. The regionalization procedure averages the chance variations from sampling while maintaining the variation due to the basin characteristics. Multiple-regression analysis allows definition of predictive equations in the form

$$
\log Q=\log C+a \log X_{1}+b \log X_{2}+c \log X_{3} ;
$$

or in the alternate form

$$
Q=C X_{1} a_{2}{ }^{b} X_{3} c
$$

where

$Q=$ the discharge of selected frequency (dependent variable);

$\mathrm{X}_{1}, \mathrm{X}_{2}, \mathrm{X}_{3}=$ the basin characteristics (independent variable);

$C=$ the regression constant; and

$\mathrm{a}, \mathrm{b}, \mathrm{c}=$ regression coefficients.

In the regression process, variables that are the least significant are automatically deleted from the equation. The accuracy of the established equation is measured by the standard error of estimate, which represents the degree to which flood-peak variation is explained. 
Initially, 13 independent variables were included in the regression computations for each T-year flood. Results of the analyses showed that three of the independent variables, drainage area, coefficient of imperviousness, and the length-slope factor (table 2), would satisfactorily explain more than 98 percent of the variation in the dependent variable. Benson (1964) showed that after inclusion of three or four independent variables, additional variables usually did not appreciably decrease the regression standard error of estimate.

Drainage area (A), which is the most important variable, accounts for at least 90 percent of the flood-discharge variation and is statistically significant at the 5 percent level for all seven T-year floods. The coefficient of imperviousness (K), which is an index to urbanization, and the length-root slope ratio $(\mathrm{L} / \sqrt{\mathrm{S}})$, which is an index to lag time, account for another 8 percent of the variation. The length-slope factor is also useful in determining the effect of future straightening of the main channel.

The regional flood-frequency equations, the regression standard errors of estimate, and a minimum combined error are summarized in table 10. These equations were derived using simulated peak discharges based on the same long-term rainfall record for all sites. Therefore, the standard errors of estimate associated with the equations are smaller than the total errors. An estimate of the minimum combined error (table 10) is obtained by combining the regression standard error of estimate with the standard error of the rainfall-runoff calibration..

A flood-frequency curve for an ungaged site can be computed if the variables are determined by the methods used in this report and are not outside the observed range. The best results will be obtained for $\mathrm{T}-$ year floods between 1.25 and 50 years for drainage areas between 4 and 15 square miles ( 12.9 and 38.8 square kilometers), $\mathrm{L} / \sqrt{\mathrm{S}}$ values between 0.7 and 1.5 , and $K$ values between 1.1 and 1.6 .

\section{Flood-Frequency Nomograph}

To aid in application of the flood-frequency equations, a nomograph (fig. 8) was developed by using simplified equations for the four highest T-year discharges $\left(Q_{10}, Q_{25}, Q_{50}, Q_{100}\right)$. The simplification involved deleting $\mathrm{L} / \sqrt{\mathrm{S}}$ from the equations given in table 10 , leaving $\mathrm{A}, \mathrm{K}$, and the regression constant $C$. To prepare the nomograph, it was assumed that the variation of the exponents of the variables was insignificant above the 10-year flood discharge so that average exponents could be used for $A$ and 


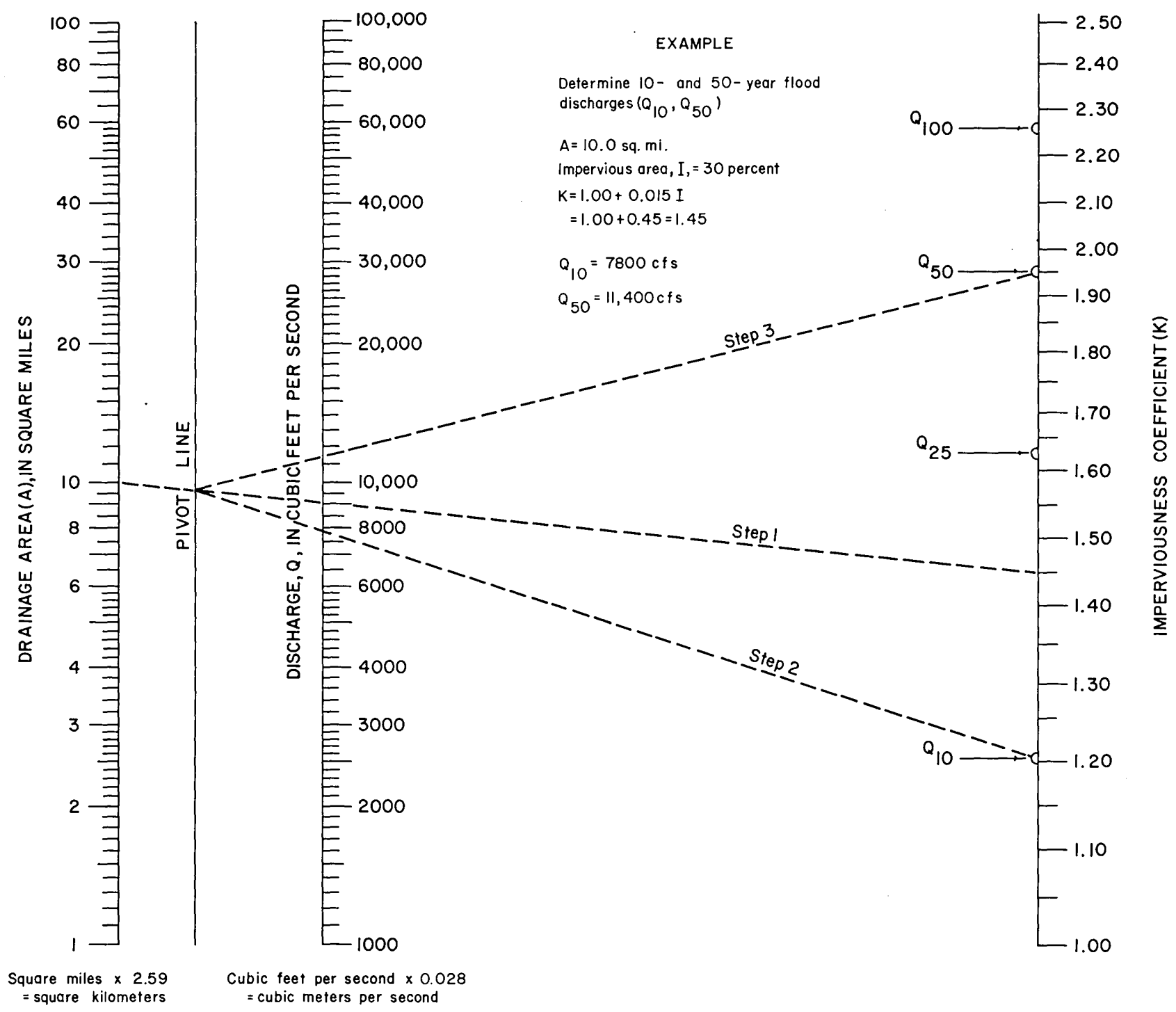

FIGURE 8.-Nomograph showing the relation between flood frequency, drainage area, and a coefficient of imperviousness 
Table 10.--Regional flood-frequency equations

Equation for indicated

T-year flood discharge (cfs) I/
Standard error

of estimate

(percent)
Estimate of minimum prediction error (percent)

$Q_{1.25}=195(A)^{0.88}(L / \sqrt{S})^{-0.13}(K)^{1.02}$

11

30

$Q_{2}=369(A)^{0.90}(I / \sqrt{S})^{-0.19}(K)^{0.65}$

11

30

$Q_{5}=621(A)^{0.93}(I / \sqrt{S})^{-0.23}(K)^{0.42}$

10

29

$Q_{10}=776(\mathrm{~A})^{0.95}(\mathrm{~L} / \sqrt{\mathrm{S}})^{-0.25}(\mathrm{~K})^{0.35}$

10

29

$Q_{25}=953(A)^{0.98}(L / \sqrt{S})^{-0.27}(K)^{0.32}$

10

29

$Q_{50}=1,067(A)^{1.00}(L / \sqrt{S})^{-0.28}(K)^{0.32}$

10

29

$Q_{100}=1,172(A)^{1.02}(L / \sqrt{S})^{-0.29}(K)^{0.33}$

where:

$Q=$ discharge in cubic feet per second (cfs)

$A=$ drainage area in square miles ( $\mathrm{sq} \mathrm{mi}$ )

$\mathrm{L}=$ length in miles ( $\mathrm{mi}$ )

$S=$ slope in feet per mile $(\mathrm{ft} / \mathrm{mi})$

$K=$ coefficient of imperviousness

1/ Cubic feet per second $\times 0.0283168=$ cubic meters per second. 
and $\mathrm{K}$. The regression constant $\mathrm{C}$ is included in the nomograph by the positioning of each T-year variable. The simplified equations used to determine the nomograph were:

$$
\begin{aligned}
& Q_{10}=1150 \mathrm{~A} \cdot 78 \mathrm{~K} \cdot 36 \\
& Q_{25}=1460 \mathrm{~A} \cdot 78 \mathrm{~K} \cdot 36 \\
& Q_{50}=1660 \mathrm{~A} \cdot 78 \mathrm{~K} \cdot 36 \\
& Q_{100}=1870 \mathrm{~A} \cdot 78 \mathrm{~K} \cdot 36
\end{aligned}
$$

EFFECT OF URBANIZATION ON FLOOD RUNOFF

Changes in Flood Peaks

Solutions to equations in table 10 can yield the following analogies:

1. When the imperviousness is increased from 0 to 40 percent, $\mathrm{Q}_{2}$ is increased about 35 percent, $\mathrm{Q}_{10}$ is increased about 18 percent, and $Q_{50}$ is increased about 16 percent.

2. When the imperviousness is increased from 0 to 100 percent, $Q_{2}$ is increased about 80 percent, $Q_{10}$ is increased about 40 percent, and $Q_{50}$ is increased about 35 percent.

3. When $\mathrm{L}$ is decreased and (or) $\mathrm{S}$ is increased, the T-year flood is increased.

These analogies are consistent with the results found in hydrologic studies of other urban areas. However, the degree of the effect of impervious area on peak discharge is not as great in Dallas as it is in Houston (Johnson and Sayre, 1973) or other coastal areas. A comparison of the 50year peak discharges, as a result of urbanization in the Dallas and Houston areas is shown on figure 9. As indicated by figure 9, the channels in Dallas, even before urbanization, are capable of much better conveyance of floods than are the channels in the Houston area even after urbanization. The small increase in the magnitude of peak discharges in the Dallas area after urbanization may be caused by the following factors:

1. The channel conveyance conditions before urbanization are good, with the channels relatively straight and free of vegetation.

2. The soil cover in the Dallas area is thin.

3. Both side and channel slopes are relatively steep. 


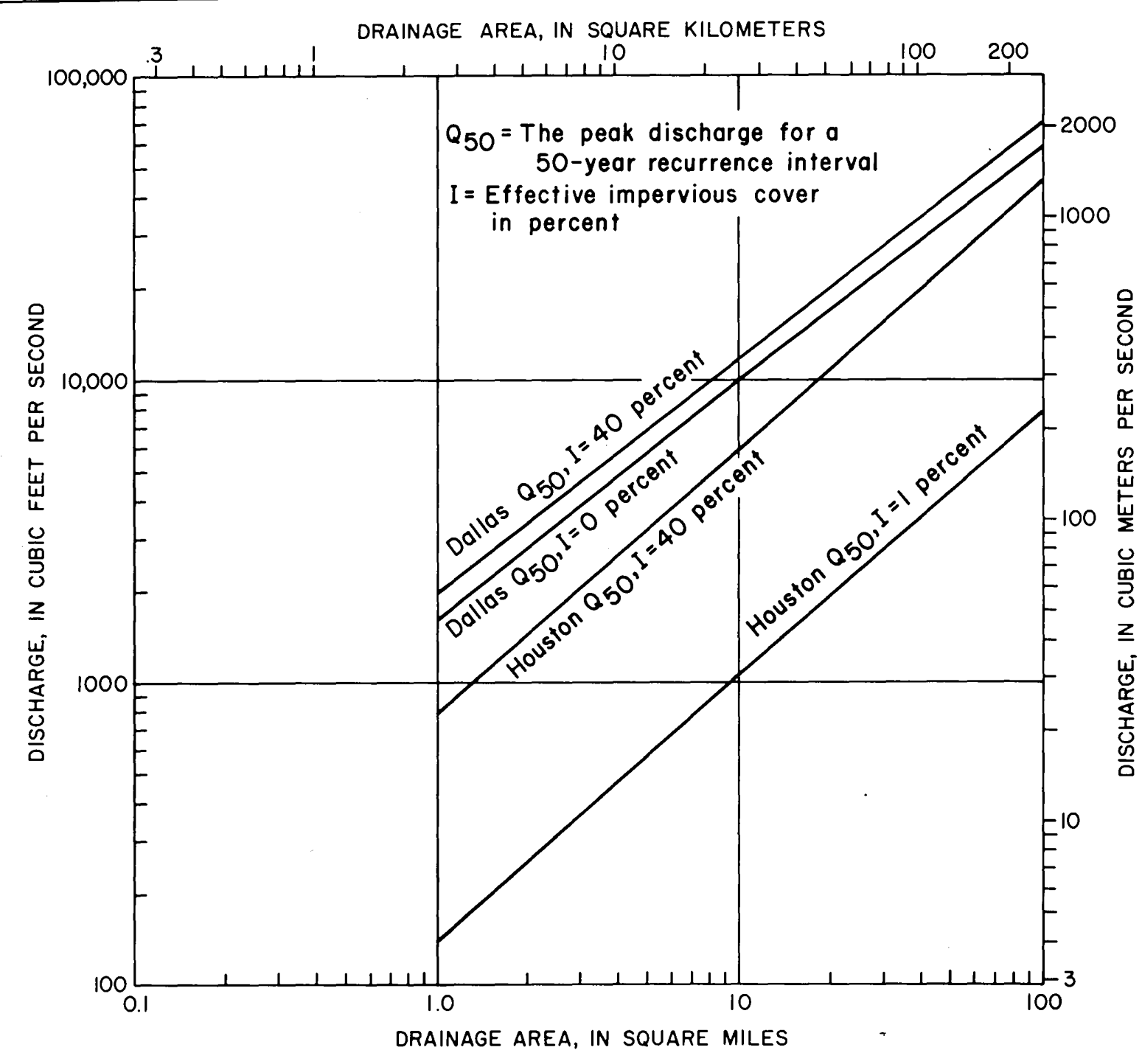

FIGURE 9.-Comparison showing the effects of urbanization on the 50-year peak discharges in Dallas and Houston 
4. Low on-channel dams and yard terracing effectively reduce the peak discharges.

5. Structures built across channels tend to retard large flows.

6. After urbanization, topsoil is introduced into residential areas, thus increasing the depth of soils.

7. Excavation of rock for septic tanks and foundations tend to increase the infiltration rate.

\section{Changes in the Volume of Annual Runoff}

Continuous runoff data are available since 1962 at four gaging stations in three basins--Bachman Branch, Turtle Creek, and White Rock. Creek basins (fig. 3). White Rock Creek Basin above Keller Springs Road is a rural basin; the intervening area between Keller Springs Road and Greenville Avenue is mostly urbanized. Bachman Branch Basin and Turtle Creek Basin are urban basins.

To estimate the approximate increase in annual runoff due to urbanization, the total and estimated direct runoff at the four gaging stations were compared. To determine the volume of annual direct runoff, hydrographs of average daily discharge for each water year were used.

The daily values of base flow were subtracted from the corresponding values of total flow for the estimated periods of direct runoff, and these differences were summed to obtain the annual volume of direct runoff. To account for the differences in drainage areas and for rainfall variability, the annual volumes of total and direct runoff were expressed as a percentage of rainfall that was computed by using appropriate rain-gage combinations and weighting methods.

Annual rainfall and runoff data for the four gaging stations and from the intervening part of White Rock Creek Basin between Keller Springs Road and Greenville Avenue are given in table 11. The data show that the average base flow is about 7 percent of the total runoff. The data also show that the urbanized basins have larger percentages of runoff.

To determine the approximate increase in runoff due to urbanization, the ratios of direct runoff in urban areas to direct runoff in rural areas were computed (table 11) for 1962-70. Figure 10 shows these ratios for the different basins, with the rural-basin ratio equal to 1.00 plotted against the percentage of effective impervious area in each basin (table 2). 


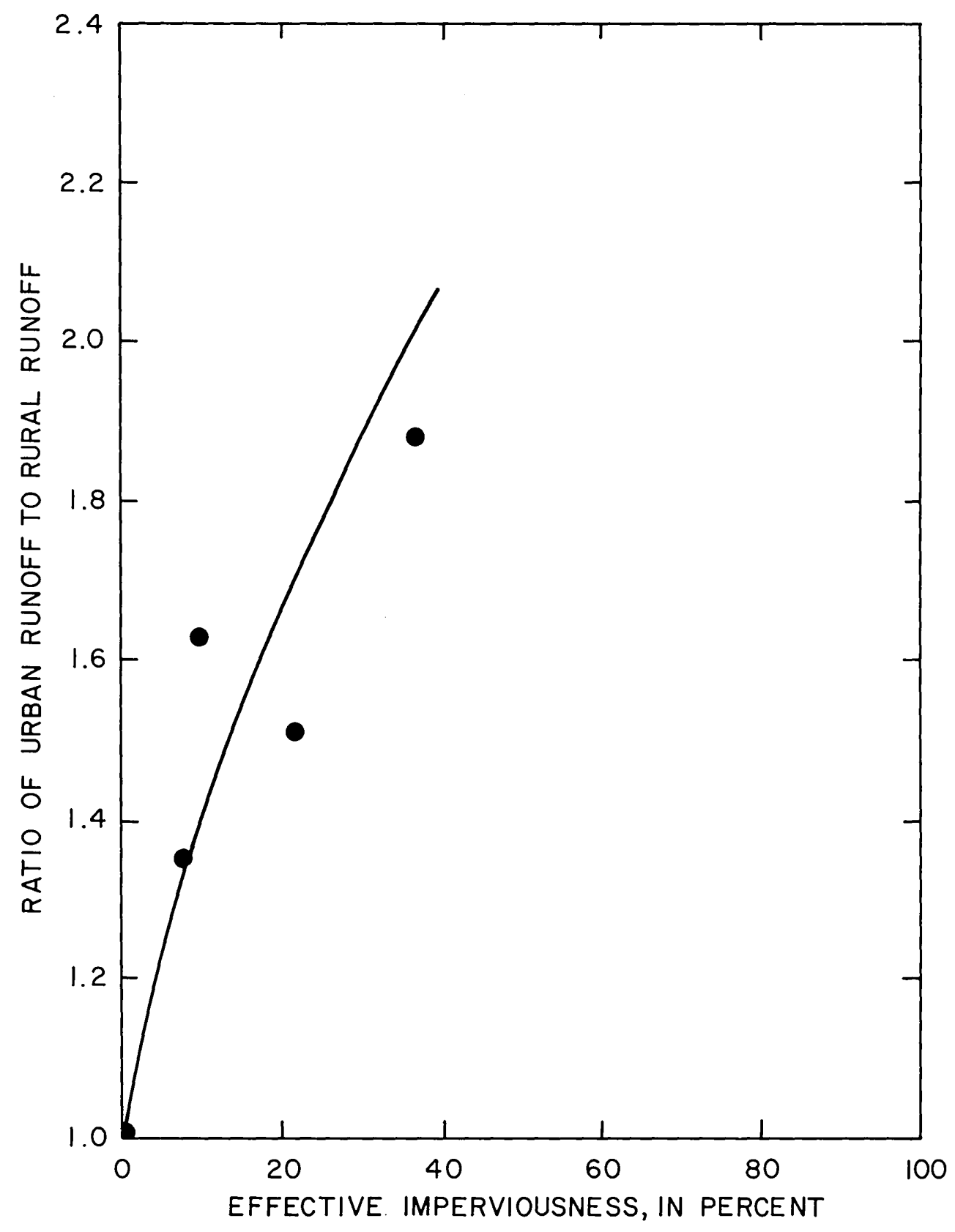

FIGURE 10.- Relation of effective impervious area to the ratio of urban runoff to rural runoff 
Table 11.--Annual rainfall and runoff in selected basins 1962-70

\begin{tabular}{|c|c|c|c|c|c|c|c|c|}
\hline $\begin{array}{l}\text { Water } \\
\text { year }\end{array}$ & $\begin{array}{c}\text { Precipi- } \\
\text { tation } \\
\text { (inches) }\end{array}$ & $\begin{array}{c}\text { Total runoff } \\
\text { (percent of } \\
\text { precipitation) }\end{array}$ & $\begin{array}{l}\text { Direct runoff } \\
\text { (percent of } \\
\text { precipitation) }\end{array}$ & $\begin{array}{c}\text { Precipi- } \\
\text { tation } \\
\text { (inches) }\end{array}$ & $\begin{array}{c}\text { Total runoff } \\
\text { (percent of } \\
\text { precipitation) }\end{array}$ & $\begin{array}{l}\text { Direct runoff } \\
\quad \text { (percent of } \\
\text { precipitation) }\end{array}$ & $\begin{array}{c}\text { Precipi- } \\
\text { tation } \\
\text { (inches) }\end{array}$ & $\begin{array}{l}\text { Direct runoff } \\
\text { (percent of } \\
\text { precipitation) }\end{array}$ \\
\hline & \multicolumn{8}{|c|}{ White Rock Creek } \\
\hline & \multicolumn{3}{|c|}{$\begin{array}{c}\text { above Keller Springs Road } \\
\text { (No. } 8-571 \text { ) }\end{array}$} & \multicolumn{3}{|c|}{$\begin{array}{c}\text { above Greenville Avenue } \\
\text { (No. 8-572) }\end{array}$} & \multicolumn{2}{|c|}{$\begin{array}{l}\text { between Keller Springs } \\
\text { Road and Greenville Avenue }\end{array}$} \\
\hline $\begin{array}{l}1962 \\
1963 \\
1964 \\
1965 \\
1966 \\
1967 \\
1968 \\
1969 \\
1970 \\
\end{array}$ & $\begin{array}{l}43.75 \\
22.72 \\
43.61 \\
36.45 \\
42.97 \\
26.13 \\
35.99 \\
35.96 \\
43.66 \\
\end{array}$ & $\begin{array}{l}22.7 \\
18.7 \\
30.6 \\
31.5 \\
28.3 \\
10.0 \\
25.4 \\
25.5 \\
18.6 \\
\end{array}$ & $\begin{array}{r}18.2 \\
9.7 \\
30.2 \\
21.8 \\
25.0 \\
6.9 \\
18.2 \\
18.8 \\
13.1 \\
\end{array}$ & $\begin{array}{l}45.11 \\
25.93 \\
41.77 \\
37.74 \\
46.42 \\
28.04 \\
38.53 \\
34.81 \\
41.87 \\
\end{array}$ & $\begin{array}{l}30.0 \\
26.8 \\
30.7 \\
40.2 \\
39.1 \\
16.5 \\
32.9 \\
35.5 \\
30.2 \\
\end{array}$ & $\begin{array}{l}24.0 \\
16.1 \\
28.1 \\
31.5 \\
34.5 \\
13.4 \\
22.7 \\
27.5 \\
20.5 \\
\end{array}$ & $\begin{array}{l}45.56 \\
27.00 \\
41.16 \\
38.18 \\
47.55 \\
28.71 \\
39.38 \\
34.46 \\
41.27 \\
\end{array}$ & $\begin{array}{l}28.8 \\
21.3 \\
25.8 \\
39.3 \\
42.4 \\
18.4 \\
26.6 \\
34.3 \\
26.4 \\
\end{array}$ \\
\hline Average & 36.80 & 23.5 & 18.0 & 37.80 & 31.3 & 24.3 & 38.14 & 29.3 \\
\hline Ratio & - & - & 1.00 & - & - & 1.35 & $=$ & 1.63 \\
\hline \multicolumn{4}{|c|}{$\begin{array}{c}\text { Bachman Branch } \\
\text { (No. 8-557) }\end{array}$} & \multicolumn{3}{|c|}{$\begin{array}{l}\text { Turtle Creek } \\
\text { (No. 8-565) }\end{array}$} & & \\
\hline $\begin{array}{l}1962 \\
1963 \\
1964 \\
1965 \\
1966 \\
1967 \\
1968 \\
1969 \\
1970 \\
\end{array}$ & $\begin{array}{c}- \\
- \\
34.57 \\
36.00 \\
44.50 \\
26.13 \\
39.97 \\
36.08 \\
44.37 \\
\end{array}$ & $\begin{array}{c}- \\
- \\
28.8 \\
38.5 \\
45.6 \\
14.4 \\
40.0 \\
35.3 \\
35.6 \\
\end{array}$ & $\begin{array}{r}- \\
- \\
24.1 \\
27.5 \\
39.3 \\
10.2 \\
31.4 \\
29.5 \\
28.4 \\
\end{array}$ & $\begin{array}{l}43.75 \\
28.46 \\
32.03 \\
38.79 \\
46.82 \\
24.62 \\
40.64 \\
36.28 \\
43.36 \\
\end{array}$ & $\begin{array}{l}38.7 \\
41.6 \\
44.6 \\
45.0 \\
49.7 \\
31.7 \\
39.3 \\
44.4 \\
42.6 \\
\end{array}$ & $\begin{array}{l}30.7 \\
33.6 \\
37.7 \\
36.6 \\
43.4 \\
23.6 \\
29.0 \\
36.2 \\
34.2 \\
\end{array}$ & 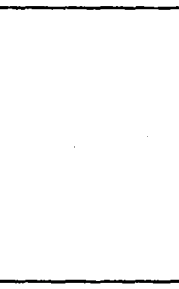 & \\
\hline Average & 37.37 & 34.0 & 27.2 & 37.19 & 42.0 & 33.9 & & \\
\hline Ratio & - & - & 1.51 & - & - & 1.88 & & \\
\hline
\end{tabular}


The trend of the data points on figure 10 show that the runoff ratios increase with increasing impervious area, indicating that urbanization increases the volume of direct runoff. The curve shown on figure 10 was fitted to the data by the method of least squares.

Thirty-seven percent effective impervious area (Turtle Creek Basin) is about the maximum for fully developed residential basins in Dallas. At 37 percent effective impervious area, average annual direct runoff is about double that of an undeveloped area. Sufficient data have not been collected in a highly industrialized area, where the effective impervious area approaches 100 percent, to determine the increase in runoff.

\section{SUMMARY AND CONCLUSIONS}

The collection of streamflow and rainfall data in and near Dallas during the period 1962-70 has afforded a definition of some of the hydrologic effects attributable to urban development. A digital model of streamflow response to rainfall and evaporation input was calibrated for watersheds with different degrees of urban development as reflected by impervious area.

The rainfall-runoff relations were used with a 57-year record of rainfall to simulate annual peak discharges at 14 sites. Frequency curves were then prepared from these peak discharges, and from these, the discharges corresponding to recurrence intervals of $1.25,2,5,10,25,50$, and 100 years were obtained.

The discharges at these recurrence intervals were related to drainage area, length-root slope ratio, and percentage of impervious area by multiple-regression techniques. These regional relations provide a method of estimating the flood-peak characteristics at ungaged sites. Based on these analyses, changing a rural basin to a fully developed residential urban basin will increase the flood peak at the 2-year recurrence interval by about 1.4 times, at the 10-year recurrence interval by about 1.2 times, and at the 50-year recurrence interval by about 1.2 times.

The data indicated that runoff in a fully developed residential area of about 40 percent effective impervious cover would be about double that of an undeveloped area. 


\section{REFERENCES CITED}

Benson, M. A., 1964, Factors affecting the occurrence of floods in the Southwest: U.S. Geol. Survey Water-Supply Paper 1580-D, 72 p.

Carter, R. W., 1961, Magnitude and frequency of floods in suburban areas: U.S. Geol. Survey Prof. Paper 424-B, p. B9-B11.

Dalrymple, Tate, 1960, Flood-frequency analyses: U.S. Geol. Survey WaterSupply Paper 1543-A, 80 p.

Dawdy, D. R. Lichty, R. W., and Bergmann, J. M., 1972, A rainfall-runoff simulation model for estimation of flood peaks for small drainage basins: U.S. Geol. Survey Prof. Paper 506-B, 28 p.

Johnson, S. L., and Sayre, D. M., 1973, Effects of urbanization on floods in the Houston, Texas metropolitan area: U.S. Geol. Survey WaterResources Inv. 3-73, 50 p.

Linsley, R. K., Jr., Kohler, M. A., and Paulhus, J. L., 1958, Hydrology for engineers: New York, McGraw-Hill Book Co., Inc., 340 p.

Mills, W. B., and Schroeder, E. E., 1969, Floods of April 28, 1966, in the northern part of Dallas, Texas: U.S. Geol. Survey Water-Supply Paper 1870-B, 37 p., 18 figs., 2 pls.

Philip, J. R., 1954, An infiltration equation with physical significance: Soil Sci. Soc. Am. Proc., v. 77, p. 153-157.

Riggs, H. C., 1968, Some statistical tools in hydrology: U.S. Geol. Survey Tech. Water-Resources Inv., book 4, chap. A1, 15 p.

Sherman, L. K., 1932, Streamflow from rainfall by the unit hydrograph method: Eng. News Record, v. 108, p. 501-505.

U.S. Water Resources Council, 1967, A uniform technique for determining floodflow frequencies: U.S. Water Resources Council Bu11. 15,

$15 \mathrm{p}$. 